\title{
A Numerical Study on the Impact of Soil Freezing
}

\author{
on the Continental-Scale Seasonal Cycle
}

\author{
By Kumiko Takata \\ Domestic Research Fellow, National Institute for Environmental Studies, Onogawa, Tsukuba, Japan \\ and \\ Masahide Kimoto \\ Center for Climate System Research, University of Tokyo, Meguro, Tokyo, Japan
}

(Manuscript received 18 May 1999, in revised form 20 January 2000)

\begin{abstract}
The thermal and hydrological impacts of soil freezing on the climate system are studied using an atmospheric general circulation model. The difference between runs with and without soil freezing, i.e., including and excluding the latent heat of fusion and the impermeability of frozen soil, shows that the inclusion of soil freezing leads to higher surface temperature in middle and high latitudes over land in summer. This leads to larger water vapor flux and precipitation in Southeast Asia. The higher temperature over land in summer results from lower evaporation caused by lower surface soil moisture. The low surface soil moisture is caused by additional runoff of snowmelt in spring due to the impermeability of frozen soil and low soil liquid water due to underlying frozen ground. Precipitation is lower in the middle of the Eurasian and North American Continents due to the lower evaporation. The sensitivity of temperature change to soil moisture change is high in regions where potential evaporation is high. In winter, deep soil temperature is higher with soil freezing in frozen ground regions due to the latent heat of freezing, but the surface temperature difference is governed more by atmospheric dynamical responses. The signs of the impacts are found to be the same in one-dimensional experiments with various hydrological schemes and parameters.
\end{abstract}

\section{Introduction}

Exchange processes between land and atmosphere are widely recognized as important in the climate system, since they are sensitive to near-surface atmospheric conditions and land surface characteristics, making the surface flux variable. For example, a strong feedback effect exists between soil moisture and evaporation; snow cover alters the surface heat budget by drastic changes in surface albedo; and, variations in snow mass affect the surface water budget. Yasunari et al. (1991) pointed out that both these effects of snow in spring may significantly affect summer monsoon intensity.

A number of studies using an atmospheric gen-

Corresponding author: Kumiko Takata, Domestic Research Fellow, National Institute for Environmental Studies, 16-2 Onogawa, Tsukuba 305-0053, Japan. E-mail: takata@nies.go.jp

(C)2000, Meteorological Society of Japan eral circulation model (AGCM) have been made on the impacts of land surface processes, e.g., desertification (e.g., Charney et al. 1977; Shukla and Mintz 1982), deforestation (e.g., Henderson-Sellers and Gornitz 1984; Dickinson and Kennedy 1992; Bonan et al. 1992), soil moisture change on weather forecasting (e.g., Walker and Rowntree 1977; Rowell and Blondin 1990) and on atmospheric variability (Delworth and Manabe 1989; Koster and Suarez 1995). They show considerable effects of land surface processes on the atmosphere.

Frozen ground is another phase of soil moisture. Permafrost, defined as soil whose temperature is below the freezing point for at least two consecutive years, covers $14 \%$ of global land. Ground freezes so extensively, including seasonal and diurnal freezing, as to cover nearly $70 \%$ of the land surface (Kinoshita 1982). In addition to this large coverage, frozen soil has a large apparent heat capacity due to 
the latent energy of freezing and thawing, and acts as an impermeable layer because of the large reduction in its hydraulic conductivity when frozen. Soil freezing could therefore greatly affect thermal and hydrological land surface conditions both in magnitude and on a spatial scale, thus playing an important role in energy and water cycles on a continental scale (Takata and Kimoto 1998).

Global warming is an important issue in frozen ground and climate studies, since warming is presumed to be greatest in the northern high latitudes in winter (IPCC 1996a). This would lead to considerable increase in active layer thickness, disappearance of discontinuous permafrost (IPCC 1996b), and reduction in wetlands due to increased evaporation (Woo 1990). Changes in frozen ground in global warming have been estimated using long-term observational data (Rouse et al. 1992; Lafleur and Rouse 1995; Osterkamp and Lachenbruch 1990; Gavrilova 1993), an empirical index (Anisimov and Nelson 1997), or physically based models (Kane et al. 1991; Hinzman and Kane 1992; Waelbroeck 1993). All, however, consider a one-way process, i.e., frozen ground response to atmospheric forcing. Mitchell and Warrilow (1987) alone studied the role of frozen ground in doubling $\mathrm{CO}_{2}$ considering interactive processes between the land surface and atmosphere, i.e., using the Meteorological Office AGCM. They showed that increased summer dryness in northern middle and high latitudes under doubled $\mathrm{CO}_{2}$ climate simulated by many AGCMs is reduced, or even reversed, by considering runoff over frozen ground.

\subsection{Modeling studies of frozen ground}

A number of numerical studies on frozen ground have been made using one-dimensional vertical models based on physical governing equations. These include heat conduction models (e.g., Nakano and Brown 1972; Grigorjan et al. 1989) and thermal and hydrological models (e.g., Taylor and Luthin 1978; Flerchinger and Saxton 1989). Many of these models, however, were developed from an engineering point of view to be used for short-term simulations of a few months and paid little attention to energy and water conservation. Only a few were developed for use in climate studies (e.g., Bonan 1991). Fully interactive processes between land and atmosphere cannot be studied adequately using one-dimensional models alone.

In contrast, AGCM is useful in studying landatmosphere interactions including frozen ground. Land surface processes and frozen ground are usually considered simply in AGCMs. Within 46 AGCMs developed by 33 research groups participating in the Atmospheric Model Intercomparison Project I (AMIP-I; Phillips 1995), soil temperature is not calculated in six models, soil moisture is prescribed in eight, a "bucket" model is used in 20 , and freezing and melting of soil moisture, i.e., the effects of latent heat of fusion and impermeability of frozen soil, are referenced in only 11 .

Few attempts have been made by AGCMs to clarify the roles of frozen ground in the climate system. Wilson et al. (1987) studied the sensitivity of surface air temperature in northern high latitudes to land surface parameters, one of which is the active layer depth, i.e., frozen ground is specified as an active layer depth. They found that the response is small when the active layer depth is altered, while changes in other parameters, such as vegetation coverage and soil albedo, yielded appreciable responses. Viterbo et al. (1999) studied the impact of soil freezing with an interactive landsurface process using the European Centre for Medium-Range Weather Forecasts (ECMWF) AGCM. They found that the latent heat of freezing and melting plays a crucial role in reducing near surface cold bias in winter that clearly benefits $2 \mathrm{~m}$ temperature forecasts, and in reducing the annual temperature cycle in soil that leads to considerable warming of the model's near surface winter climate over continental areas. Their study concentrated on the thermal impact of soil freezing, not touching on the hydrological impact.

\subsection{Objectives of this study}

Soil freezing is expected to have significant effects on energy and water cycles in the climate system as stated above, but few studies have been made on this, particularly taking into consideration the interaction between land and atmosphere. The purpose of this paper is to study the interactive impacts of soil freezing from thermal and hydrological points of view using an AGCM. This study focuses on continental-scale impact because frozen ground is distributed on such a scale. Frozen ground impact is thought to be important on long time scales, such as interdecadal, centennial and glacial, because frozen ground has a large apparent heat capacity due to latent heat of fusion. This study, however, focuses on the annual cycle as a first step because it is very noticeable in the climate system.

Integrations of an AGCM with and without soil freezing are conducted, and the impacts of soil freezing studied based on the difference between the two experiments. The response of these experiments may be disputable, however, due to rather simple land surface parameterization. The sensitivity of the impacts to land surface schemes and parameters is therefore examined using a one-dimensional land surface model forced by atmospheric observational data. The AGCM is briefly described in Section 2, experiments described in Section 3, and simulated climatology validated in Section 4. Impacts of soil freezing and sensitivity are studied in Sections 5 and 6 , and a discussion and conclusions presented in Sections 7 and 8 . 


\section{Model}

An atmospheric general circulation model developed by Numaguti et al. (1995) (CCSR/NIES AGCM) is used with a multi layer soil model. The AGCM simulates global motion of the atmosphere with the solar incidence as energy input, and with real orography as a lower boundary condition. It includes a radiation scheme (Nakajima et al. 1995), a cumulus scheme simplified from Arakawa and Schubert (1974), prognostic cloud water (Le Treut et al. 1991), a turbulence closure scheme (Mellor and Yamada 1982), and an orographic gravity wave drag parameterization (McFarlane 1987). In this study, the horizontal resolution is about $600 \mathrm{~km}$ (T21), and the vertical resolution is 20 layers between the surface and $10 \mathrm{hPa}$. Sea surface temperature is prescribed using climatological monthly means.

The soil model is $2 \mathrm{~m}$ in depth with three layers $(0-5,5-40$, and $40-200 \mathrm{~cm})$. Soil temperature $T$ is predicted using a thermal conduction equation with a modification for the latent heat of fusion:

$$
\frac{\partial c T}{\partial t}=\frac{\partial}{\partial z}\left(\kappa \frac{\partial T}{\partial z}\right)+L_{i} \rho_{w} \frac{\partial \theta_{i}}{\partial t}
$$

where $c$ is volumetric heat capacity of soil, $\kappa$ thermal conductivity, $L_{i}$ latent heat of fusion, $\rho_{w}$ water density and $\theta_{i}$ volumetric ice content (water equivalent).

Soil moisture is calculated by the diffusion equation of volumetric liquid soil moisture content, $\theta_{w}$ :

$$
\frac{\partial \theta_{w}}{\partial t}=\frac{\partial}{\partial z}\left(D \frac{\partial \theta_{w}}{\partial z}\right)
$$

where $D$ is soil moisture diffusivity. Globally uniform values are specified for $c, \kappa$, and $D$. Soil moisture flux is assumed to be zero when part of soil moisture in an adjacent layer is frozen. Frozen soil actually has a discernible permeability (Baker and Spaans 1997), however. The present formulation yields maximum effects of change in permeability due to soil freezing. The effect of frozen soil permeability is examined in Section 6. Excess soil moisture beyond saturation in each layer is extracted from soil as runoff and exits the system.

The phase change process is modeled by an isothermal approach (Shoop and Bigl 1997), i.e., a freezing or thawing layer is considered as isother$\mathrm{mal}$ and to have a temperature equal to the freezing point during a computational time step. The change in volumetric ice ratio $\Delta \theta_{i}$ (water equivalent) in time step $\Delta t$ is written as

$$
\begin{aligned}
& \Delta \theta_{i} \\
& =\left\{\begin{array}{l}
\min \left(\frac{c}{\rho_{w} L_{i}}\left(T_{f}-\tilde{T}\right), \theta_{w}\right) \cdots \tilde{T}<T_{f} \\
\max \left(\frac{c}{\rho_{w} L_{i}}\left(T_{f}-\tilde{T}\right),-\theta_{i}\right) \cdots \tilde{T}>T_{f}
\end{array}\right.
\end{aligned}
$$

where $\min (a, b)$ denotes a function to take the lower between $a$ and $b, \max (a, b)$ a function to take the higher between $a$ and $b, T_{f}$ the freezing point $273.15 \mathrm{~K}, \tilde{T}$ the soil temperature derived from heat conduction (the first term on the right side of Eq. (1)). The upper part of Eq. (3) denotes freezing and the lower part thawing. Figure 1a schematically diagrams Eq. (3). $\Delta \theta_{i}$ is positive when $\tilde{T}$ is lower than $T_{f}$ (freezing); $\Delta \theta_{i}$ is negative when $\tilde{T}$ is higher than $T_{f}$ (melting). Then $\tilde{T}$ is corrected for the latent heat of fusion using $\Delta \theta_{i}$ as

$$
\begin{aligned}
T & =\tilde{T}+\frac{\rho_{w} L_{i}}{c} \Delta \theta_{i} \\
& =\left\{\begin{array}{l}
T_{f} \cdots \Delta \theta_{i}=\frac{c}{\rho_{w} L_{i}}\left(T_{f}-\tilde{T}\right) \\
\tilde{T}+\frac{\rho_{w} L_{i}}{c} \Delta \theta_{w} \cdots \Delta \theta_{i}=\theta_{w} \\
\tilde{T}-\frac{\rho_{w} L_{i}}{c} \Delta \theta_{i} \cdots \Delta \theta_{i}=-\theta_{i}
\end{array} .\right.
\end{aligned}
$$

Soil temperature is equal to $T_{f}$ during freezing or thawing (uppermost line of Eq. (4)). When it is fully frozen, soil temperature is increased from $\tilde{T}$ by latent heat of freezing for $\theta_{w}$ but remains below $T_{f}$ (middle line of Eq. (4)). When it is fully thawed, soil temperature is decreased from $\tilde{T}$ by latent heat of melting for $\theta_{i}$ but remains above $T_{f}$ (bottom line of Eq. (4); see Fig. 1b).

Snow amount (water equivalent) $S$ is calculated from the balance equation of snow fall $P_{s}$, snowmelt $M$, and sublimation $E_{s}$ as

$$
\frac{\partial S}{\partial t}=P_{s}-E_{s}-M
$$

Precipitation is judged as snowfall when the dew point at the lowest atmospheric level is below the freezing point. Snowmelt is calculated similarly to the isothermal approach for soil thawing, and sublimation is calculated from the same equation as other fluxes at the surface.

The surface fluxes of momentum, sensible heat, and latent heat $F_{i}$ are estimated by a bulk formula (Louis 1979) as

$$
F_{i}=k \rho C_{i}\left|\mathbf{v}_{a}\right|\left(i_{s}-i_{a}\right)
$$

where $\rho$ is air density, $C_{i}$ bulk coefficient, and $\left|\mathbf{v}_{a}\right|$ wind speed. $i$ stands for wind speed, temperature, and humidity for momentum, sensible and latent fluxes, respectively. Subscripts of $i, s$ and $a$, denote values at the surface and in the lowest atmospheric level. Coefficient $k$ is unity for momentum flux, the specific heat of air at a constant pressure for sensible heat flux, and evaporation efficiency $\beta$ for latent heat flux. $\beta$ is estimated from surface soil moisture $\theta_{\text {top }}$ as

$$
\begin{aligned}
& \beta=\min \left\{\frac{\theta_{t o p}}{0.75 \theta_{s}}, \frac{r_{a}}{r_{a}+r_{s} /(1+\gamma)}\right\} \\
& \gamma=\left(L / c_{p}\right)\left(\partial q^{*} / \partial T\right)
\end{aligned}
$$


(a)

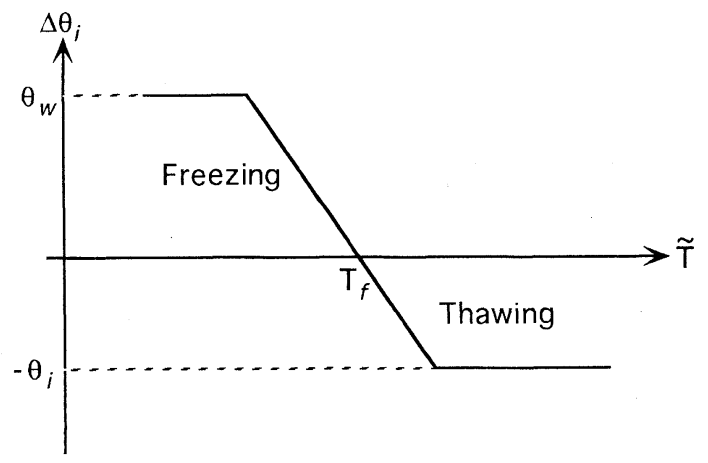

(b)

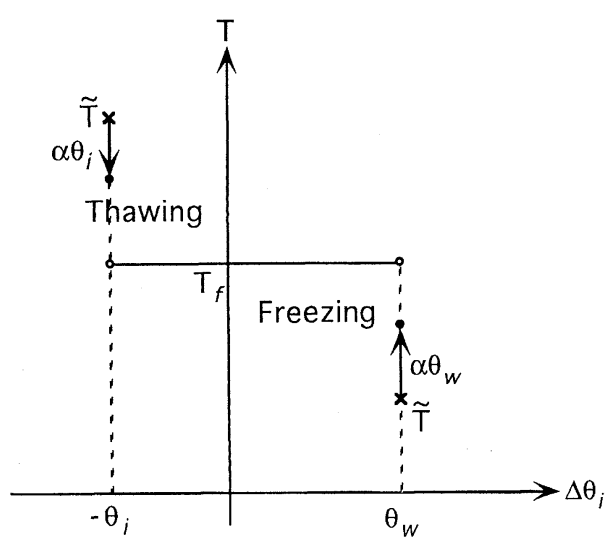

(c)

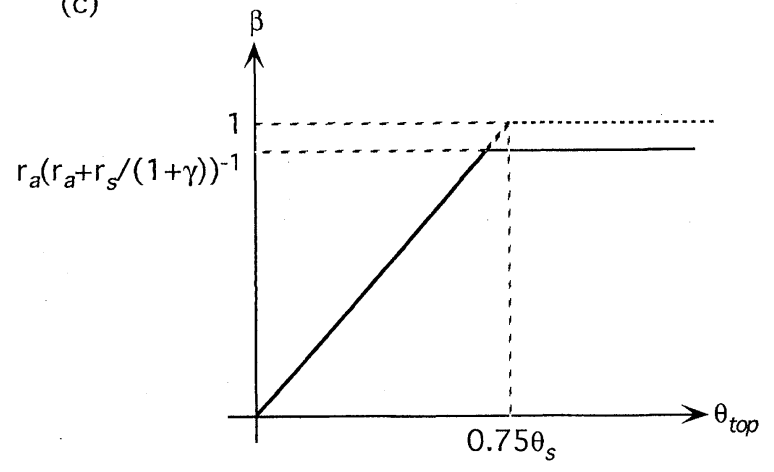

Fig. 1. (a) Schematic diagram of Eq. (3). (b) As in (a) but for Eq. (4). $\alpha$ is $\rho_{w} L_{i} / c$. (c) As in (a) but for Eq. (7).

where $\theta_{s}$ is porosity, $r_{a}=\left(C_{E}\left|\mathbf{v}_{a}\right|\right)^{-1}$ atmospheric resistance, and $r_{s}$ stomatal resistance specified at a constant value depending on vegetation type. $\beta$ takes a value near unity when $\theta_{\text {top }}$ exceeds than $75 \%$ of $\theta_{s}$, and decreased linearly with $\theta_{\text {top }}$ (Fig. 1c).

\section{Experiments}

Two types of experiments are conducted, i.e., with ( $\mathrm{F}$ run) and without ( $\mathrm{N}$ run) freezing and thawing processes of soil. In the $\mathrm{N}$ run, soil moisture exists as supercooled water when the soil temperature is below the freezing point. Switching off soil freezing has two effects - where latent heat of freezing and thawing is ignored, and where the impermeability of frozen ground is ignored.

The initial atmospheric condition is an isothermal, motionless state. It takes 10 years to obtain equilibrated seasonal cycles with soil freezing and 5 years without. It takes longer with soil freezing than without because the water cycle is slower. The model is integrated for another 20 years and the mean of the last 20 years is used to calculate the climatological annual cycle. The difference in climatology between $\mathrm{F}$ and $\mathrm{N}$ runs $(\mathrm{F}-\mathrm{N})$ is used to examine the impacts of freezing, using 10-day mean data.

\section{Simulated climatology}

The CCSR/NIES AGCM's reproducibility of climate in $\mathrm{F}$ and $\mathrm{N}$ runs is similar to that in Numaguti et al. (1995). Performance of an AGCM is generally changed little by revising one process in the AGCM, e.g., the landsurface process, because it depends on many other processes, such as cumulus convection, radiative transfer, and turbulent transport, and on the balances among them. Surface air temperature, precipitation, and snow cover are closer to the observations in some regions and seasons of the F run, but are closer to observations in other regions and seasons of the $\mathrm{N}$ run; it cannot be judged easily which run is closer to observation. The differences of the two present runs from observation are similar to those of AMIP (Atmospheric Model Intercomparison Project) AGCMs (e.g., Mao and Robock 1998), thus the climates in the runs are equally realistic as the AMIP AGCMs. Therefore, we concentrate in this study on describing the differences between the two runs, i.e., the impact of soil freezing, without claiming that it should lead to a better model climate. The simulated climate in frozen ground regions is shown below.

Figure 2 shows the calculated global distribution of frozen ground in the F run. Seasonally frozen ground (Fig. 2a), defined as regions where the annual maximum of frozen ratio $\left(\theta_{i} /\left(\theta_{w}+\theta_{i}\right)\right)$ in the uppermost layer equals unity for 10-day means, is distributed north of $30^{\circ}-40^{\circ} \mathrm{N}$ on the Eurasian and North American Continents. Permafrost (Fig. 2b), defined as the region where the annual minimum of $\theta_{i} /\left(\theta_{w}+\theta_{i}\right)$ in the bottom layer exceeds zero, is distributed in Alaska, northern Canada, and eastern Siberia. Both are very similar to those estimated from observations by Dostovalov and Kudryavtsev (1967), except for the absence of permafrost on the Tibetan plateau. This is probably due to the discontinuous distribution of permafrost there and the smoothed topography at the coarse horizontal resolution of the model. Although the horizontal resolution of T21 is rather coarse, the large-scale field is reproducible, e.g., large-scale monsoon circulations are captured by the AGCM with T21 resolution as shown in Shen et al. (1998). 
(a)

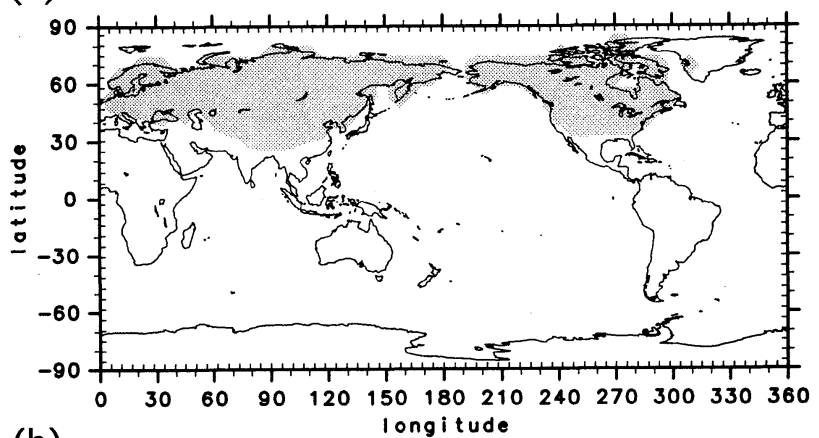

(b)

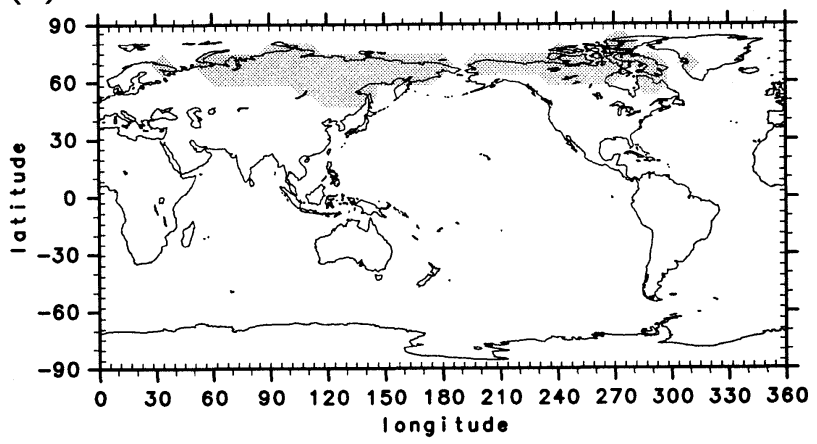

Fig. 2. (a) Calculated distribution of seasonally frozen ground. Shadings denote regions where the annual maximum of the 10-day mean frozen ratio in the uppermost layer equals unity. (b) Calculated distribution of permafrost. Shadings denote regions where the annual minimum of the 10-day mean frozen ratio in the bottom layer exceeds zero.

Calculated soil moisture is compared to observed data at five stations in seasonally frozen ground regions of Russia (Robock et al. 1995), to evaluate the hydrological condition. Soil moisture calculated at grid points nearest to these stations is used for comparison. Ratios of available soil moisture (liquid plus ice) to saturation are used, namely, for model results,

$$
W_{g} / W_{s}
$$

is used where $W_{g}$ is calculated soil moisture and $W_{s}$ saturated soil moisture, while for the observation,

$$
\left(W-W_{\text {wilt }}\right) /\left(W_{\text {total }}-W_{\text {wilt }}\right)
$$

is used where $W$ is soil moisture measured by a thermostat-weight technique, $W_{\text {wilt }}$ is wilting level, and $W_{\text {total }}$ is total water-holding capacity. Figure 3 shows annual cycles of 20-year mean $W_{g} / W_{s}$ in the upper two layers $(0-40 \mathrm{~cm})$, and $(W-$ $\left.W_{\text {wilt }}\right) /\left(W_{\text {total }}-W_{\text {wilt }}\right)$ in the upper $0-50 \mathrm{~cm}$ averaged for $1978-1983$ observations. $W_{g} / W_{s}$ is higher in winter than in summer and has maximum in snowmelt season similar to $\left(W-W_{\text {wilt }}\right) /\left(W_{\text {total }}\right.$ $\left.W_{\text {wilt }}\right)$. Simulated maxima lag behind observations at Khabarovsk, Tulun, Uralsk, and Yershov, however, because snowmelt at these points in the model climate occurs later by about 1-month than the observation. Relative differences in soil moisture variations among the five stations are captured well by the model. The soil moisture ratio agrees better with observations in the $\mathrm{F}$ run than in the $\mathrm{N}$ run at Khabarovsk, Tulun, Uralsk, and Yershov, but better in the $\mathrm{N}$ run at Ogurtsovo. Seasonal amplitudes agree better in the $\mathrm{N}$ run than the $\mathrm{F}$ run at Ogurtsovo and Tulun. It cannot be judged from this comparison which run simulates the surface hydrological condition better, but it can be stated that the model reproduces the annual cycle of soil moisture in frozen ground regions.

The annual cycle of the atmospheric and soil temperature and surface water fluxes in central Siberia $\left(90^{\circ}-120^{\circ} \mathrm{E}, 40^{\circ}-65^{\circ} \mathrm{N}\right)$ in the $\mathrm{F}$ run is shown in Fig. 4 to evaluate the typical thermal and hydrological annual cycle in frozen ground regions. The seasonal range of air temperature (Fig. 4a) is similar to observed climatology, e.g., the National Centers for Environmental Prediction/National Center for Atmospheric Research (NCEP/NCAR) reanalysis data. The amplitude of annual cycle in soil temperature is attenuated and its phase lags due to heat conduction (Fig. 4a) similar to observations, e.g., at Yakutsk (Takata 1998). Rain and evaporation have maxima in summer (Fig. 4b) similar to those observed at Tulun (Yang et al. 1997) located in this region. Snowmelt and runoff peak in spring as expected in snow-covered regions (Fig. 4b). Overall, thermal and hydrological annual cycles in the frozen ground region are reproduced fairly well by the AGCM.

\section{Impacts of soil freezing in the AGCM}

This section discusses the impacts of soil freezing on the climate system taking into account the difference between AGCM runs with and without soil freezing. The time sequence of the difference in central Siberia, the same region as in the previous section, is presented to examine local impacts. Then, global distributions of differences in summer and in winter are presented to investigate the continentalscale impacts and remote effects.

\subsection{Central Siberia}

The local difference between the two runs (F$\mathrm{N})$ in central Siberia was examined. Figure $5 \mathrm{a}$ shows the $\mathrm{F}-\mathrm{N}$ of atmospheric and soil temperatures by time-height section. Shadings denote statistically significant portions at the $95 \%$ confidence level judged by a Student's t-test. A small but statistically significant positive difference occurs in soil temperature near the surface in SeptemberOctober, proceeding into deep layers, then a large positive difference appears with a maximum at deep 
(a)

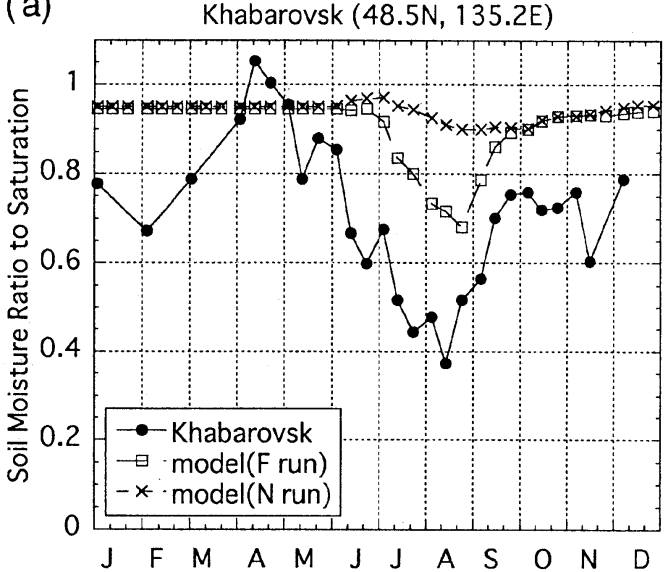

(c)

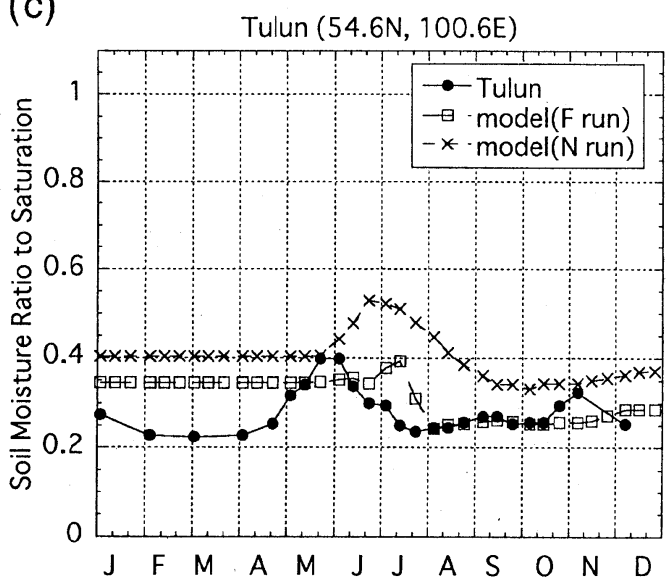

(b)

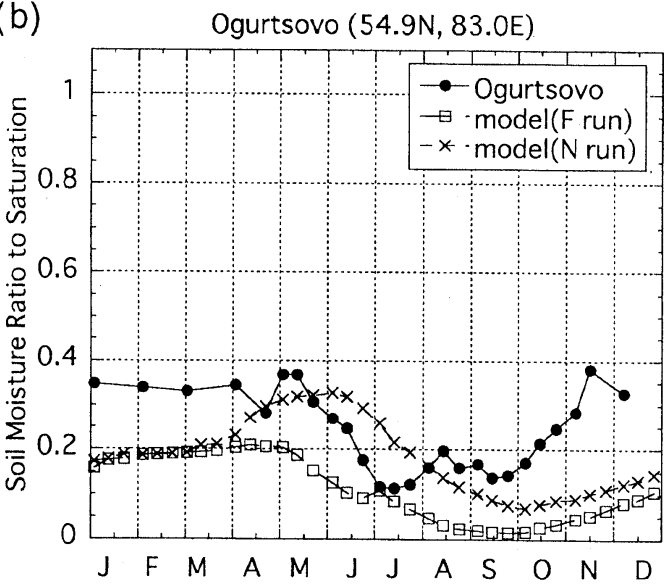

(d)

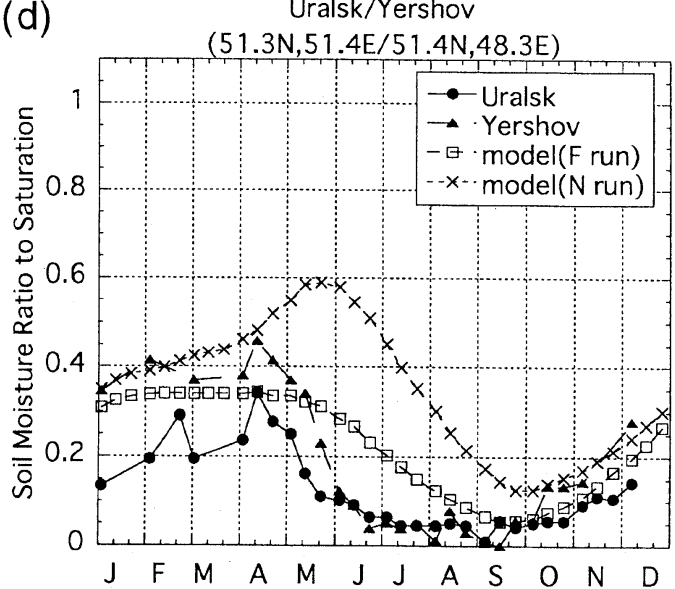

Fig. 3. Soil moisture relative to saturation at (a) Khabarovsk $\left(48.5^{\circ} \mathrm{N}, 135.2^{\circ} \mathrm{E}\right)$, (b) Ogurtsovo $\left(54.9^{\circ} \mathrm{N}\right.$, $\left.83.0^{\circ} \mathrm{E}\right)$, (c) Tulun $\left(54.6^{\circ} \mathrm{N}, 100.6^{\circ} \mathrm{E}\right)$, and (d) Uralsk $\left(51.3^{\circ} \mathrm{N}, 51.4^{\circ} \mathrm{E}\right)$ and Yershov $\left(51.4^{\circ} \mathrm{N}, 48.3^{\circ} \mathrm{E}\right)$. and $\boldsymbol{\Delta}$ denote the ratio of measured available soil moisture to saturation available soil moisture for 0-50 cm, $\left(W-W_{w i l t}\right) /\left(W_{t}-W_{\text {wilt }}\right)$, averaged from 1978 to 1983 (Robock et al., 1995). $\square$ and $\times$ denote the simulated soil moisture ratio to saturation for $0-40 \mathrm{~cm}, W_{g} / W_{s}$, with and without soil freezing, averaged for 20 years.

soil in February-March. These positive differences are brought about by the release of latent heat of freezing as the freezing front proceeds into deep soil. The difference is larger in the bottom layer than near the surface because of the higher soil moisture content. The large positive difference in deep soil temperature from winter to spring loses its magnitude toward the surface, leading to a small surface temperature difference during this period.

Another positive soil temperature difference with a maximum of a few degrees occurs near the surface in summer. Air temperature also has a large positive difference with a maximum near the surface at the same time. Large positive temperature differences near the surface in summer are explained by surface water and energy budgets, i.e., it results from the negative difference in evaporation in summer (Fig. $5 \mathrm{~b}$ ), attributed to the negative soil moisture difference in upper layers (not shown). The major factor causing the negative soil moisture difference is the higher runoff in spring (Fig. 5b) due to the impermeability of frozen ground. This relation is elaborated in the next section. The precipitation difference is negative in summer (Fig. 5b), which largely balances the negative evaporation difference.

\subsection{Continental-scale impacts in summer}

Continental-scale distributions of $\mathrm{F}-\mathrm{N}$ in summer, i.e., June-August mean (JJA hereafter), are presented in this section in order to examine remote impacts of soil freezing. Figure 6 a shows $\mathrm{F}-\mathrm{N}$ for the surface air temperature and vertically-integrated water vapor flux in JJA. Shadings indicate regions where the temperature difference is statistically significant at the $95 \%$ confidence level.

Large positive differences in surface air temperature occur over the Eurasian and North American Continents in middle and high latitudes. Southeast of the Eurasian maximum, eastward vapor flux is enhanced in the F run from Southeast Asia to the western subtropical Pacific (Fig. 6a). Magnitudes of the difference are $10-20 \%$ of the original field, 
(a)

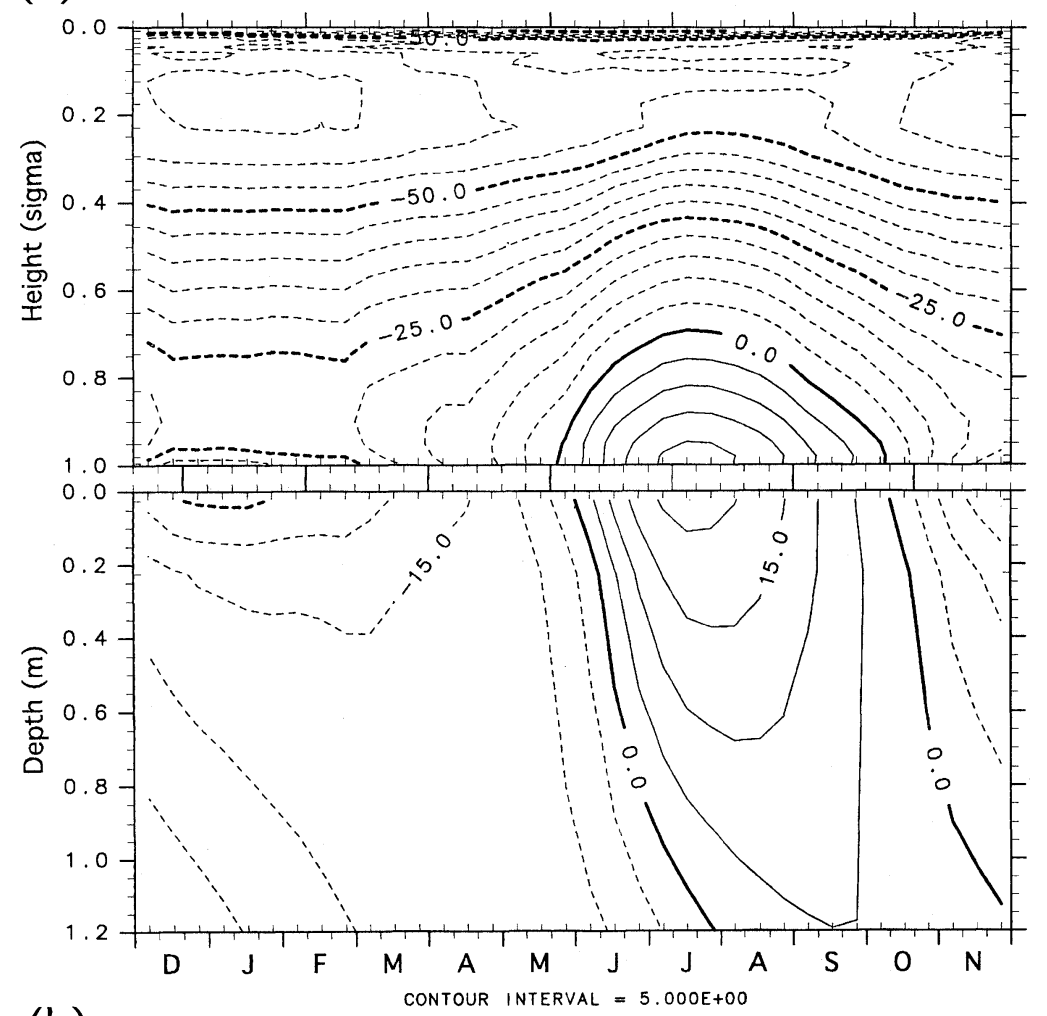

(b)

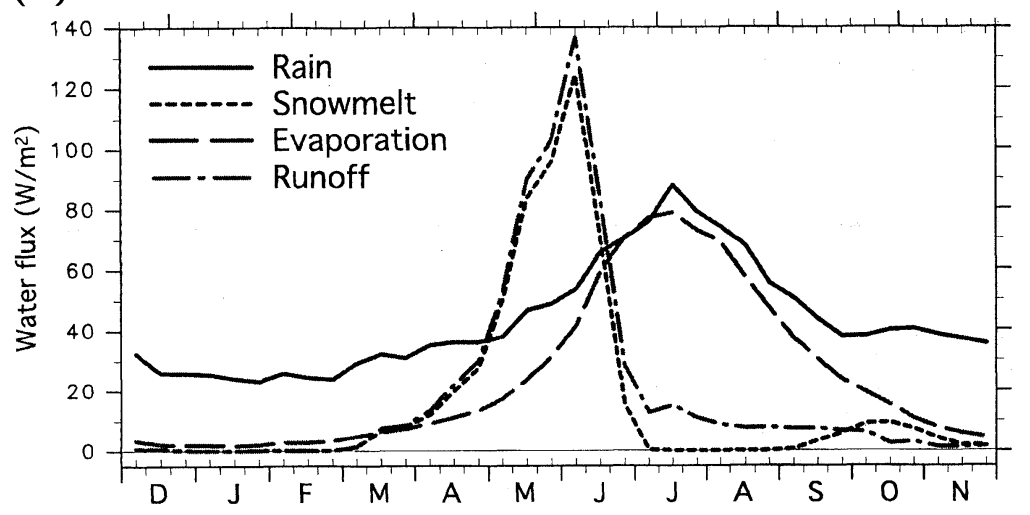

Fig. 4. Climatological seasonal cycle in central Siberia $\left(90-120^{\circ} \mathrm{E}, 40-65^{\circ} \mathrm{N}\right)$ in $\mathrm{F}$ run. (a) Time-height section of air and soil temperatures (contour interval $=5 \mathrm{~K}$, and dashed contours denote negative values). Atmospheric vertical coordinate, sigma $\sigma$, is the pressure standardized by the surface value, $p / p_{s}$. (b) Time series of rainfall (solid line), snowmelt (dotted line), evaporation (dashed line) and runoff (dash-dotted line) $\left(1 \mathrm{~W} / \mathrm{m}^{2}=1.0368 \mathrm{~mm} / \mathrm{month}\right)$.

which is statistically significant at the $95 \%$ confidence level. These differences are consistent with the higher surface temperature over land in summer that generally leads to stronger summer monsoons. Zonal wind at $850 \mathrm{hPa}$ is intensified from the North Indian Ocean to the South China Sea (not shown), similar to those in strong monsoon years shown in Fig. 18 of Webster and Yang (1992).

The precipitation is considerably enhanced in the $\mathrm{F}$ run in the above-mentioned regions where eastward vapor flux is enhanced, and reduced in the middle of the Eurasian and North American Continents (Fig. 6b). The difference in outgoing long- wave radiation (OLR) is consistent with the precipitation differences-OLR is lower where precipitation is higher and vice versa (Fig. 6c). The distribution of OLR difference in the Asian sector agrees with those in the strong monsoon years shown in Fig. 14a of $\mathrm{Li}$ and Yanai (1996). The upper tropospheric temperature, i.e., the 200-500 hPa layer mean temperature, is higher in the F run over Southeast Asia because of higher precipitation and associated latent heat release. On the other hand, it is lower in southeastern North America (Fig. 6d). This is associated with lower precipitation, since it is a local drying region. The distribution of difference in upper tropospheric 
(a)

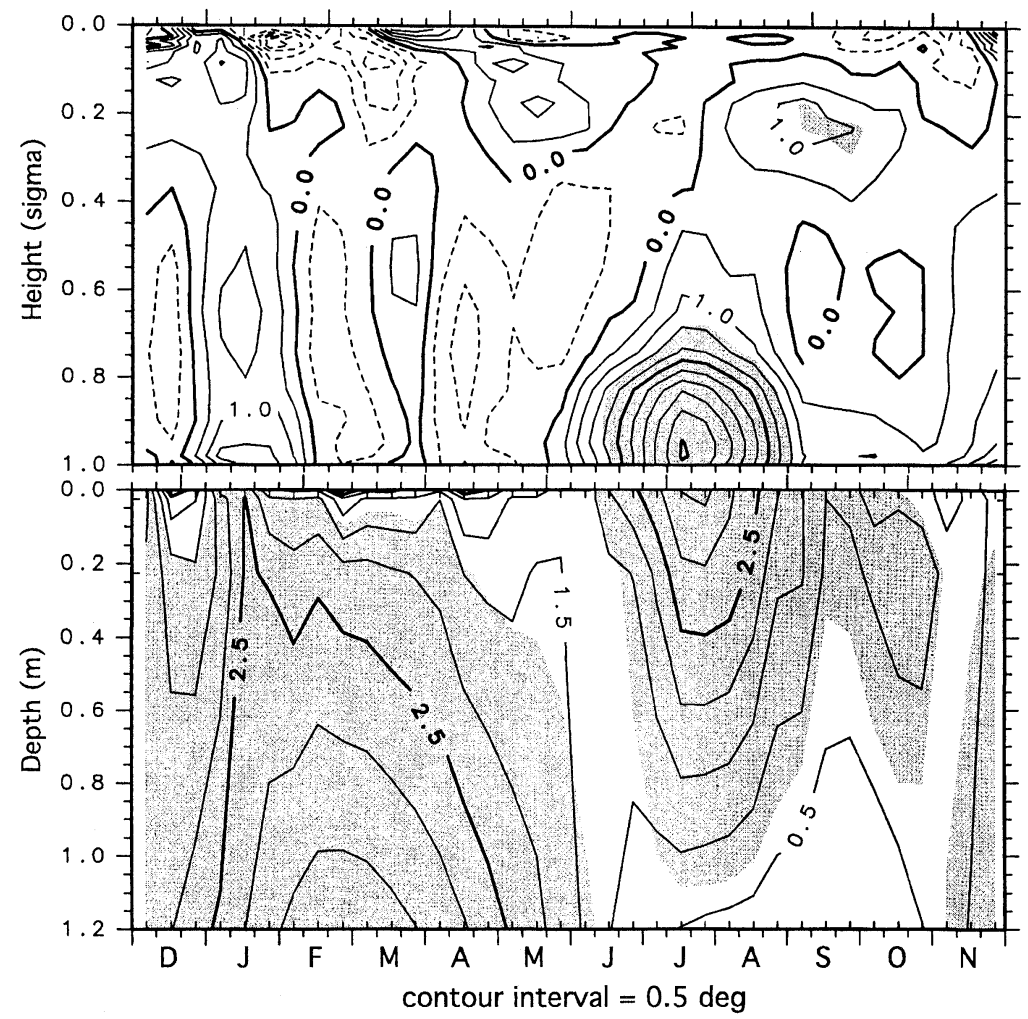

(b)

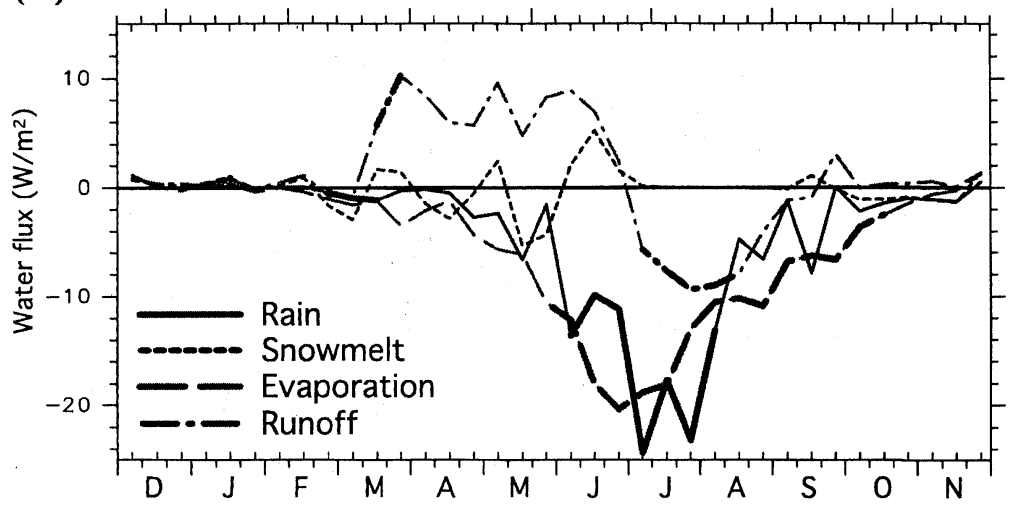

Fig. 5. As in Fig. 4, but for the difference between with and without soil freezing $(\mathrm{F}-\mathrm{N})$. The contour interval in (a) is $0.5 \mathrm{~K}$. Dashed lines denote negative values. Shadings in (a) and thick lines in (b) denote statistically significant portions at the $95 \%$ confidence level.

temperature in the Asian sector agrees with that in strong monsoon years (Fig. 12a of Li and Yanai (1996)). A wave train originating in heating over the South China Sea and extending northeastward to middle and high latitudes is seen in Fig. 6a and more marked in the $200 \mathrm{hPa}$ wind field (not shown), similar to that found by an observational analysis of western Pacific circulation variability (Nitta 1987). The introduction of soil freezing produces considerable remote impacts related to summer monsoons and large-scale circulations.

The negative precipitation differences in the middle of the Eurasian and North American Continents are attributed to the negative evaporation difference in these regions (not shown) because much of precipitating water is supplied from evaporation from the land surface in the central region of each continent (Numaguti 1999). This is also presumed from the fact that evaporation in central Siberia in JJA is nearly $90 \%$ of precipitation (Fig. $4 \mathrm{~b}$ ). The negative evaporation difference is related to a negative surface soil moisture difference, statistically significant over most of the land north of $30^{\circ} \mathrm{N}$ (Fig. 6e). The lower soil moisture, lower evaporation, and higher surface temperature are consistent with the surface water and energy budget. 
(a)


Contour interval $=10 \mathrm{~W} / \mathrm{m}^{2}(=10.368 \mathrm{~mm} / \mathrm{mon})$

Fig. 6. (a) Difference $(\mathrm{F}-\mathrm{N})$ in summer (June-August) for surface air temperature (contours every $0.5 \mathrm{~K}$ ) and vertically integrated water vapor flux (the unit arrow at bottom left corresponds to $150 \mathrm{kgm}^{-1} \mathrm{~s}^{-1}$ ). Shadings denote statistically significant regions at the $95 \%$ confidence level for temperature difference. Dashed contours denote negative values. (b) As in (a) but for precipitation (contour interval: $\left.10 \mathrm{~W} / \mathrm{m}^{2}=10.368 \mathrm{~mm} / \mathrm{month}\right)$.

As pointed out earlier, the major cause of the negative soil moisture difference in summer is the positive runoff difference in spring. The land surface hydrological processes related to the summer soil moisture difference are studied using latitude-time cross sections along $90^{\circ} \mathrm{E}$ from $0^{\circ}$ to $90^{\circ} \mathrm{N}$. Figure $7 \mathrm{a}$ shows the level of the uppermost frozen layer in the
$\mathrm{F}$ run (shadings) and the $\mathrm{F}-\mathrm{N}$ of surface soil moisture (contours). The negative soil moisture difference in summer is marked north of $60^{\circ} \mathrm{N}$ where the bottom layer remains frozen in summer (light shading). The large negative soil moisture difference in high-latitude summer is therefore attributed to the limited liquid soil moisture supply for evaporation 


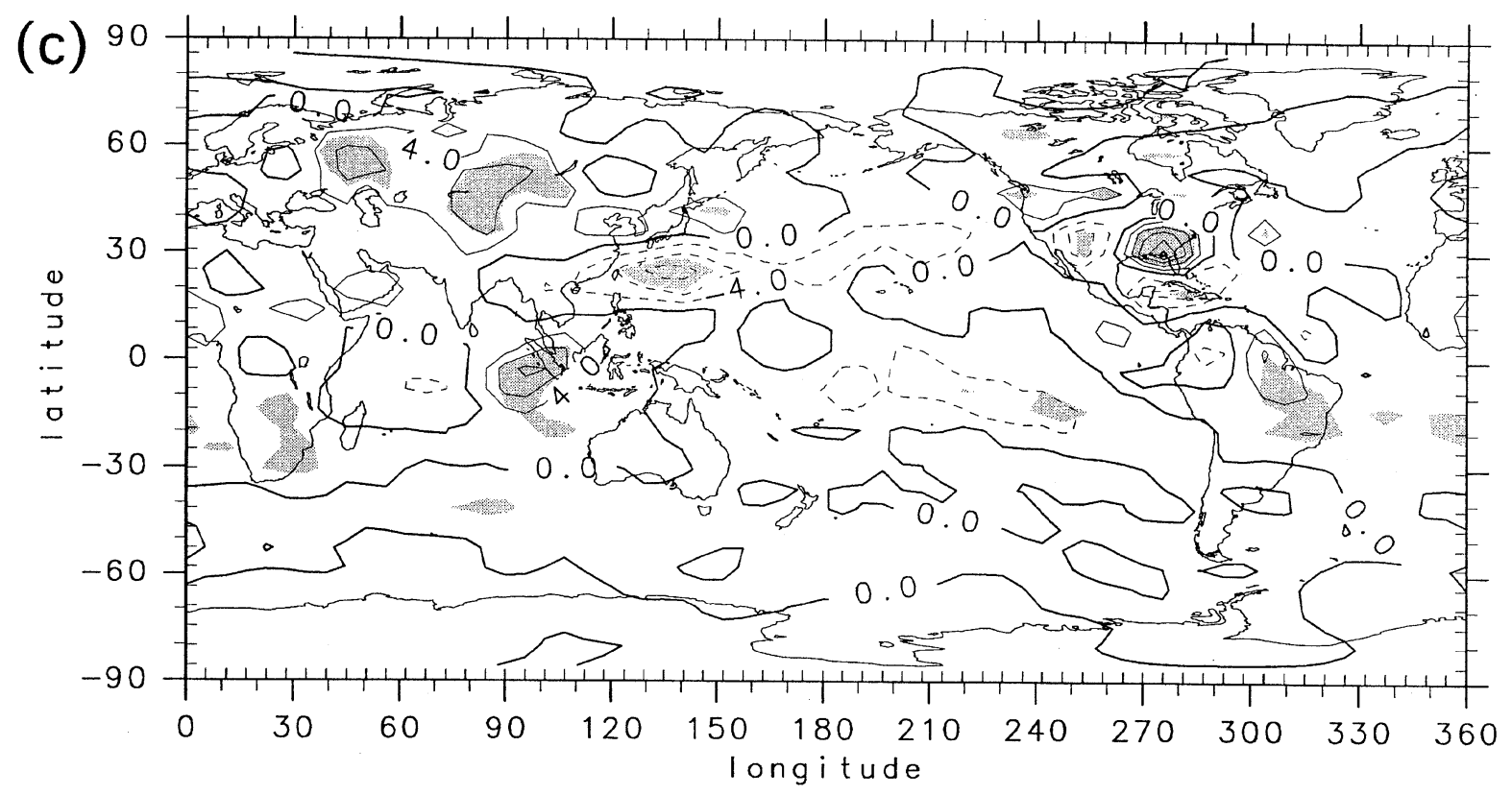

Contour interval $=4 \mathrm{~W} / \mathrm{m}^{2}$

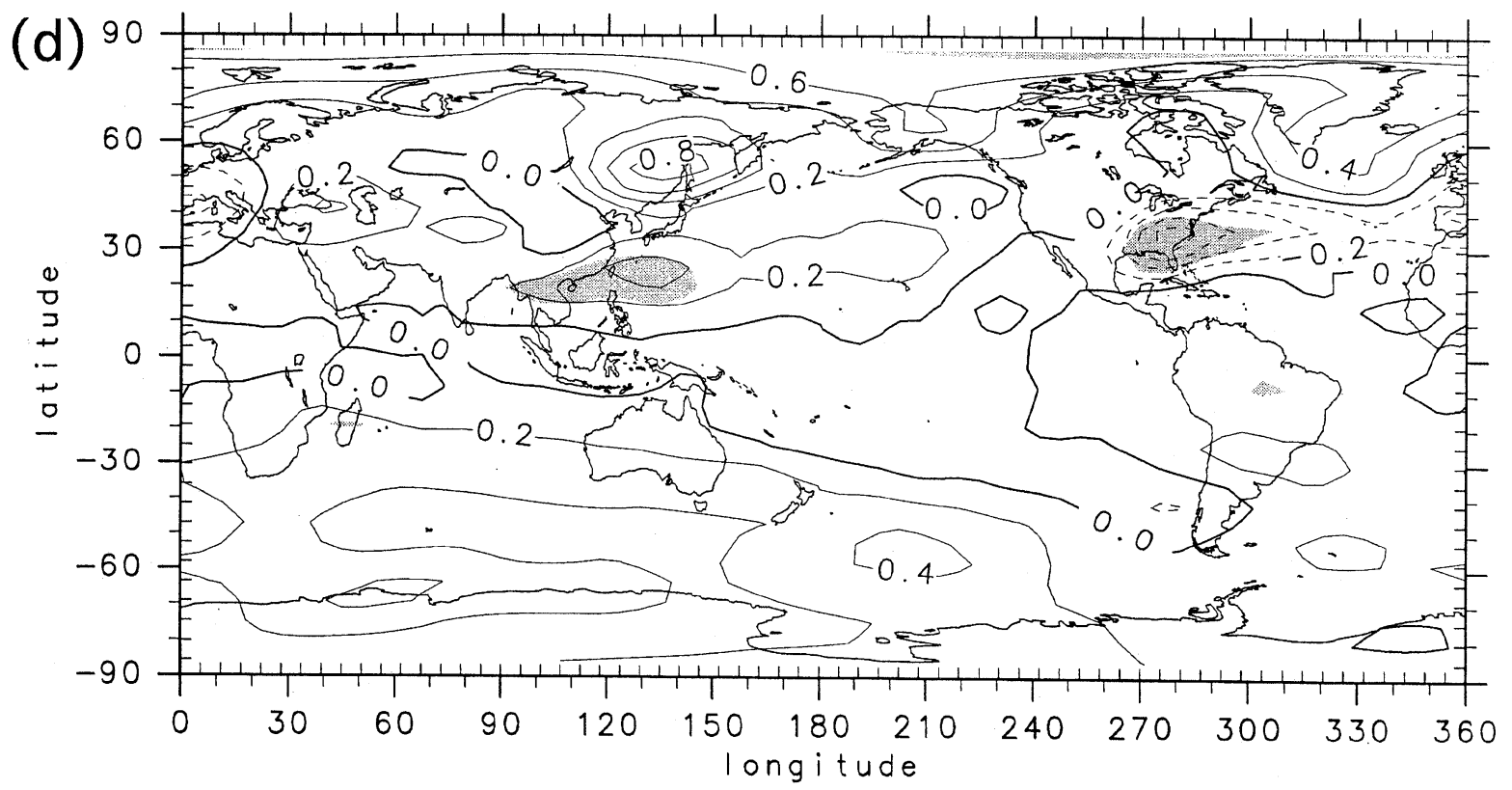

Contour interval $=0.2 \mathrm{~K}$

Fig. 6. (c) As in (a) but for OLR (contour interval: $4 \mathrm{~W} / \mathrm{m}^{2}$ ). (d) As in (a) but for mean temperature between 200 and $500 \mathrm{hPa}$ (contour interval: $0.2 \mathrm{~K}$ ).

in upper layers due to underlying frozen soil. On the other hand, the soil moisture difference is small but statistically significant between $30^{\circ} \mathrm{N}$ and $60^{\circ} \mathrm{N}$, where all soils are thawed in summer. Another reason should thus exist for the negative soil moisture difference in lower latitudes.

Net water flux at the surface is the leading term for soil moisture change. Figure $7 \mathrm{~b}$ shows the $\mathrm{F}-\mathrm{N}$ of net surface water flux calculated from liquid pre- cipitation, snowmelt, runoff, and evaporation (contours), and snow water equivalent in the $\mathrm{F}$ run (shadings). The $\mathrm{F}-\mathrm{N}$ of net surface water flux is negative between $30^{\circ} \mathrm{N}$ and $60^{\circ} \mathrm{N}$ at the end of the snow-cover season, leading to lower surface soil moisture in summer. Runoff is also higher in a similar part of the time-latitude cross section (Fig. 7c), consistent with the negative differences in surface water flux. No such change occurs in other com- 


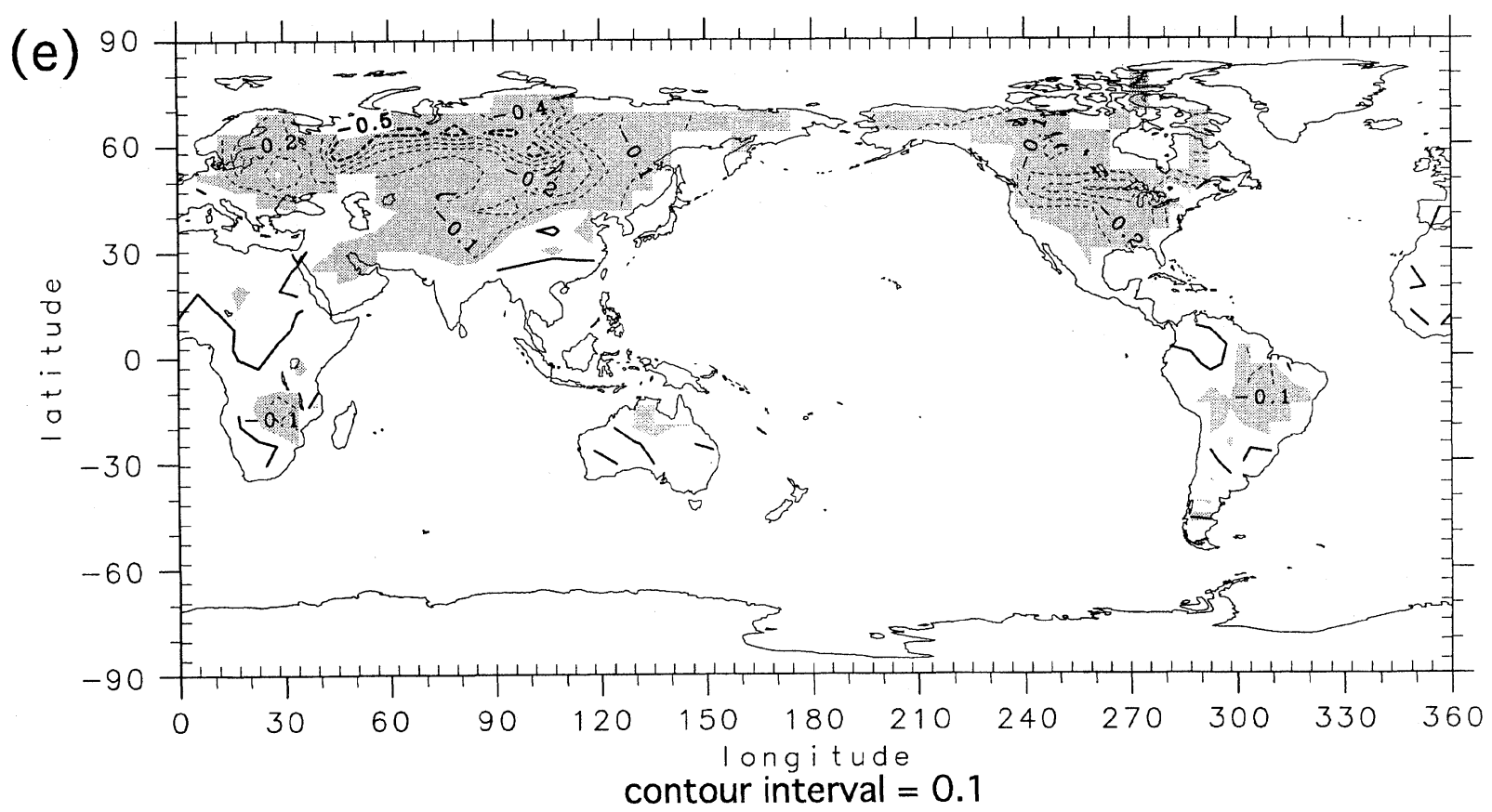

Fig. 6. (e) As in (a) but for surface soil moisture ratio to saturation (contour interval: 0.1).

ponents of surface water flux, however. The larger runoff in spring thus causes the negative soil moisture difference in summer. To determine whether these runoff differences are caused by a difference in snow amount, the $\mathrm{F}-\mathrm{N}$ of annual snowfall along $90^{\circ} \mathrm{E}$ in $0^{\circ}-90^{\circ} \mathrm{N}$ is shown in Fig. 8. The snowfall difference is negative between $30^{\circ} \mathrm{N}$ and $55^{\circ} \mathrm{N}$, which cannot lead to a larger runoff in snowmelt season. The high runoff is thus attributable to the inclusion of soil freezing, i.e., the impermeability of frozen soil. It follows that lower summertime soil moisture in the $30^{\circ}-60^{\circ} \mathrm{N}$ band results from the larger runoff of snowmelt caused by the impermeability of frozen soil, which leads to the marked local and remote impacts on the atmosphere. The effect of frozen soil impermeability increasing snowmelt runoff was also pointed out by Mitchell and Warrilow (1987), who showed that it signigicantly affects the response of summer soil moisture to the doubling of $\mathrm{CO}_{2}$.

Note that the minimum $\mathrm{F}-\mathrm{N}$ in soil moisture (Fig. 6e) is located in higher latitudes than the maximum F-N in surface air temperature (Fig. 6a). This discrepancy is examined in relation to evaporation, since lower soil moisture generally leads to lower evaporation and higher surface temperature. The F-N of evaporation has a conspicuous negative correlation with that of surface air temperature in all latitudes; the correlation coefficient is -0.78 . The positive correlation between the $\mathrm{F}-\mathrm{N}$ of evaporation and soil moisture is weak-the correlation coefficient is 0.28 -because evaporation is affected also by atmospheric stability, humidity, and wind velocity.

To simplify the relationship between evaporation and soil moisture, we represent evaporation $F_{E}$ as a product of potential evaporation $E_{p}$ and evaporation efficiency $\beta$,

$$
F_{E}=\beta E_{p}
$$

The evaporation change is written as

$$
\delta F_{E}=\delta \beta \cdot E_{p}+\beta \cdot \delta E_{p}
$$

where $\delta$ denotes difference $\mathrm{F}-\mathrm{N}$ in this study. Considering that $\delta F_{E}$ has a negative correlation with the $\mathrm{F}-\mathrm{N}$ of surface air temperature $\delta T_{a}$ and that $\beta$ is a linear function of surface soil moisture ratio to the saturation $W_{g} / W_{s}$, except when $W_{g} / W_{s}$ is higher than 0.75 (Eq. (7)), Eq. (8) is written as

$$
-a \delta T_{a}=\delta W_{g} / W_{s} \cdot E_{p}+W_{g} / W_{s} \cdot \delta E_{p}
$$

where $a$ is a constant of proportion. This relationship is examined from correlation between $\delta T_{a}$ and $\delta W_{g} / W_{s}$ (Fig. 9a), and between $\delta T_{a}$ and $\delta E_{p}$ (Fig. 9b). Symbols in Fig. 9a denote $E_{p}$ in F run, and those in Fig. 9b denote $W_{g} / W_{s}$. There is a weak negative correlation between $\delta W_{g} / W_{s}$ and $\delta T_{a}$ for the whole range of $E_{p}$; the correlation coefficient is -0.47 . The gradient of correlation is steeper where $E_{p}$ is higher, which is also deduced from the first term on the right side of Eq. (9), i.e., the gradient of $\delta T_{a}$ to $\delta \beta$ is proportional to $E_{p}$. Thus, the sensitivity of temperature change to soil moisture change is higher where potential evaporation is higher. The high sensitivity of temperature change in the region where potential evaporation is high accounts well for the discrepancy that the maximum F-N of surface 
(a)

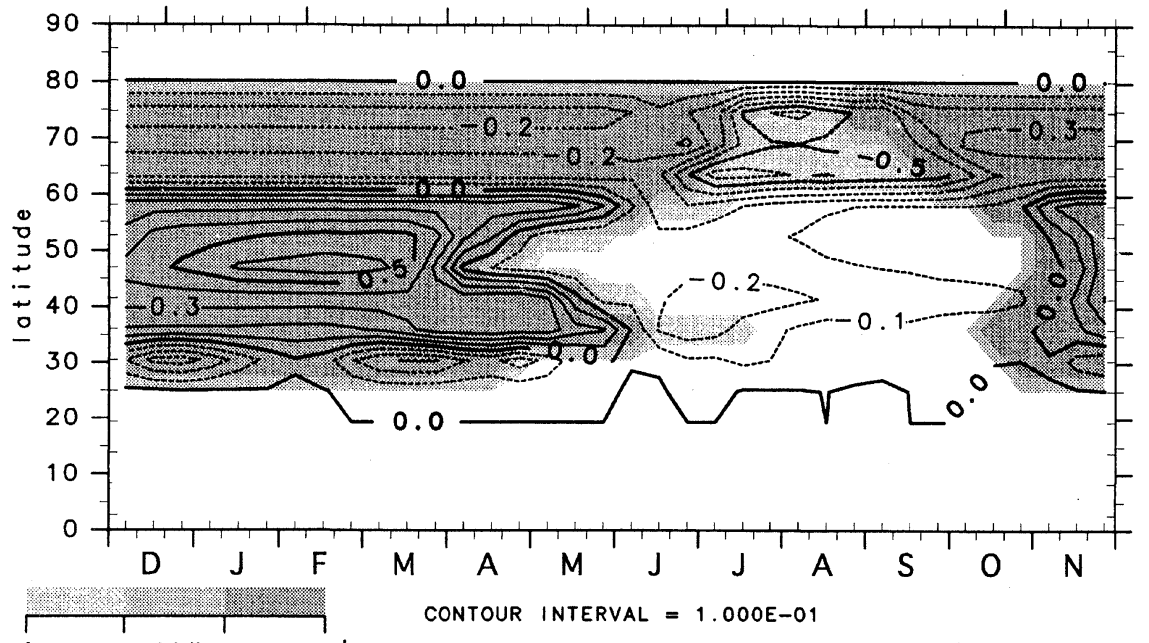

bottom middle top layer

(b)

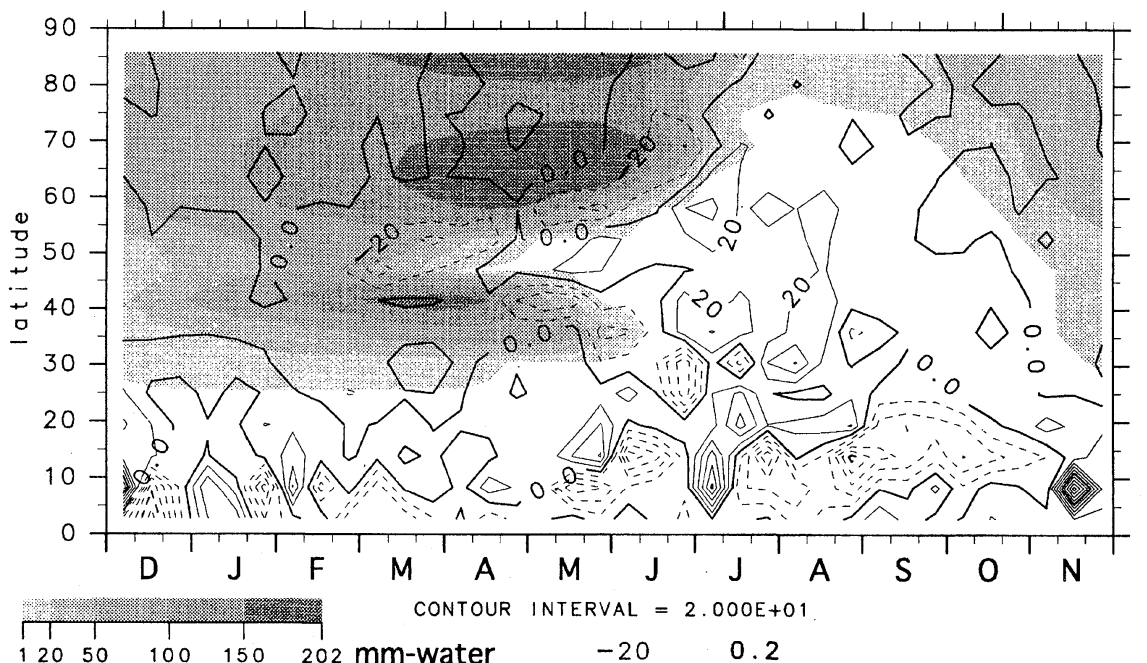

(c)

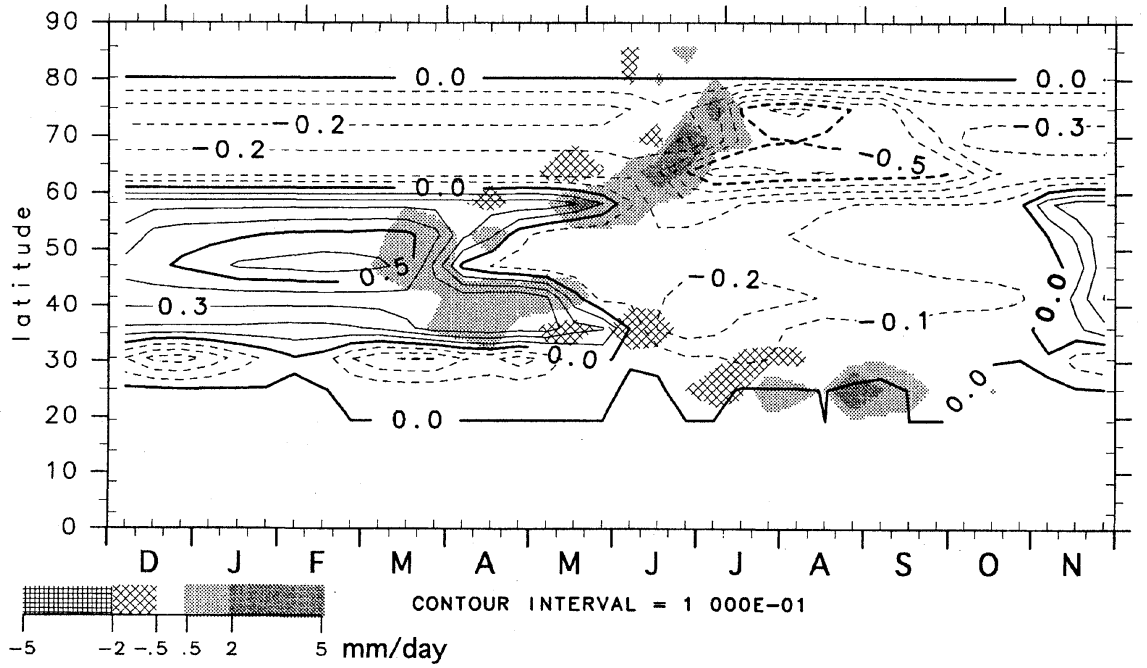

Fig. 7. Time-latitude section along $90^{\circ} \mathrm{E}$. The abscissa is time plotted from December to November. The ordinate is latitude plotted from $0^{\circ}$ to $90^{\circ} \mathrm{N}$. Dashed contours denote negative values. (a) Difference $(\mathrm{F}-\mathrm{N})$ in volumetric surface soil moisture content (contours) and the depth of the top of frozen soil in $\mathrm{F}$ run (shadings). Dark shadings denote that the top is in the upper most layer, medium shadings in the middle layer, and light shadings in the bottom layer. (b) As in (a) but for F-N in net surface water flux (contours) and in snow water equivalent in F run (mm; shadings). (c) As in (a) but for $\mathrm{F}-\mathrm{N}$ in volumetric surface soil moisture content (contours) and in runoff (mm/day; shadings). 


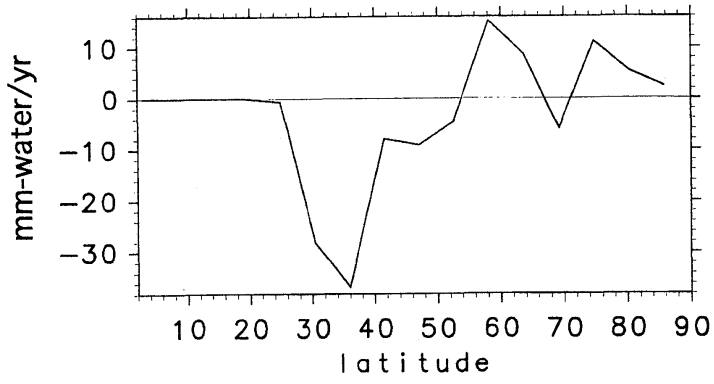

Fig. 8. Latitudinal distribution of difference $(\mathrm{F}-\mathrm{N})$ in annual snowfall along $90^{\circ} \mathrm{E}$ from $0^{\circ}$ to $90^{\circ} \mathrm{N}$.

air temperature is in lower latitudes than the minimum $\mathrm{F}-\mathrm{N}$ in soil moisture.

In contrast, the gradient of $\delta T_{a}$ to $\delta E_{p}$ changes little with respect to $W_{g} / W_{s}$ (Fig. $9 \mathrm{~b}$ ). This is due to the smaller range of $W_{g} / W_{s}$ than that of $E_{p}$, (second term, Eq. (9)). Note also that $\delta T_{a}$ is low regardless of $\delta W_{g} / W_{s}$ where $W_{g} / W_{s}$ in the $\mathrm{F}$ run exceeds 0.75 (solid squares, Fig. $9 \mathrm{~b}$ ) because $\beta$ is near unity there (Eq. (7); Fig. 1c). Changes in evaporation are thus low, and changes in temperature small-less than $1.5 \mathrm{~K}$ for these points. $\delta T_{a}$ ranges from 0 to $4 \mathrm{~K}$ where $W_{g} / W_{s}$ is lower than 0.75 , which also accounts for the high $\mathrm{F}-\mathrm{N}$ of surface air temperature in latitudes lower than those of soil moisture.

\subsection{Continental-scale impacts in winter}

The impacts of soil freezing on the atmosphere are less marked in winter than in summer partly because of thermal insulation by snow cover, and partly because of high atmospheric variability in winter. Figure 10a shows the $\mathrm{F}-\mathrm{N}$ of soil temperature in the bottom layer in winter (mean in DecemberFebruary; DJF). Large positive differences occur in frozen ground regions due to the release of latent heat of soil freezing (Section 5.1). Nevertheless, the difference in surface air temperature in DJF is positive in eastern and negative in the western Eurasian Continent in the middle and high latitudes (Fig. 10b). The latitude-height sections of the F-N in atmospheric and soil temperature along $34^{\circ} \mathrm{E}$ and $112^{\circ} \mathrm{E}$ (Fig. 11) show the contrast of local impacts between eastern and western Eurasia. Positive soil temperature differences occur in the latitudinal zone corresponding to frozen ground regions for both longitudinal sections. The positive difference in soil, however, is canceled near the surface by the negative difference in the lower atmosphere for the cross section at $34^{\circ} \mathrm{E}$ (Fig. 11a), while both are positive at $112^{\circ} \mathrm{E}$ and appear to be coupled at the surface (Fig. 11b).

The positive and negative signs of the $\mathrm{F}-\mathrm{N}$ in surface air temperature are explained by weakening Siberian high pressure in DJF indicated by negative differences in sea level pressure over the Eurasian Continent (Fig. 10c). While a positive tempera- ture difference is the overall cause of weakening of Siberian high pressure, the local difference in surface air temperature is also affected by the difference in circulation caused by weakening of the high pressure system. The weaker Siberian anticyclone enhances northerly wind over Europe and southerly wind over East Asia. These differences in circulation contribute to the negative surface temperature difference in western Eurasia and the positive difference in eastern Eurasia. The difference in pressure field tilts to the west in the upper troposphere (shadings in Fig. 10c), i.e., has a baroclinic structure, implying that it is a forced signature. A cyclonic difference over the Bering Sea and an anticyclonic difference over the northeastern Pacific apprear to be a downstream response to the difference over the Eurasian Continent. The same does not hold, however, for the differences in pressure system over North America, partly because the winter anticyclone is not so pronounced as in Eurasia and partly because it is located downstream of Eurasia.

To summarize, although soil temperature is higher in winter with soil freezing, its local impact is low because of the thermal insulation of snow cover and the weakened Siberian high pressure causing higher surface air temperature in eastern Eurasia and lower surface air temperature in western Eurasia.

\section{Sensitivity to landsurface parameteriza- tion}

It appears reasonable to conclude from AGCM experiments that soil freezing has thermal and hydrological impacts on the climate system at a continental scale. However, the land surface model used in the AGCM is so simple that it is debatable how faithfully land surface processes are reproduced and how accurately the magnitude of impacts are assessed, because the coarse vertical resolution may cause errors in calculating freezing and thawing depths, and because the magnitude of thermal and hydrological impacts depends on soil moisture content. Thermal impact, i.e., the amount of latent heat of fusion, is proportional to soil moisture content and hydrological impact, i.e., the impermeability of frozen soil, is reduced in unsaturated soil, although no soil moisture flux is assumed in the AGCM when part of soil moisture is frozen. Experiments using a one-dimensional land surface model thus were conducted to examine the sensitivity of soil freezing impacts to hydrological schemes and parameters.

The land surface submodel in the AGCM was extracted and modified as a one-dimensional model. The soil moisture schemes and parameters examined are summarized in Table 1. $\mathrm{D}(3)$ is the same as the land surface scheme in the AGCM. The number of soil layers in other experiments increases considerably from $\mathrm{D}(3)$. Three types of soil moisture 

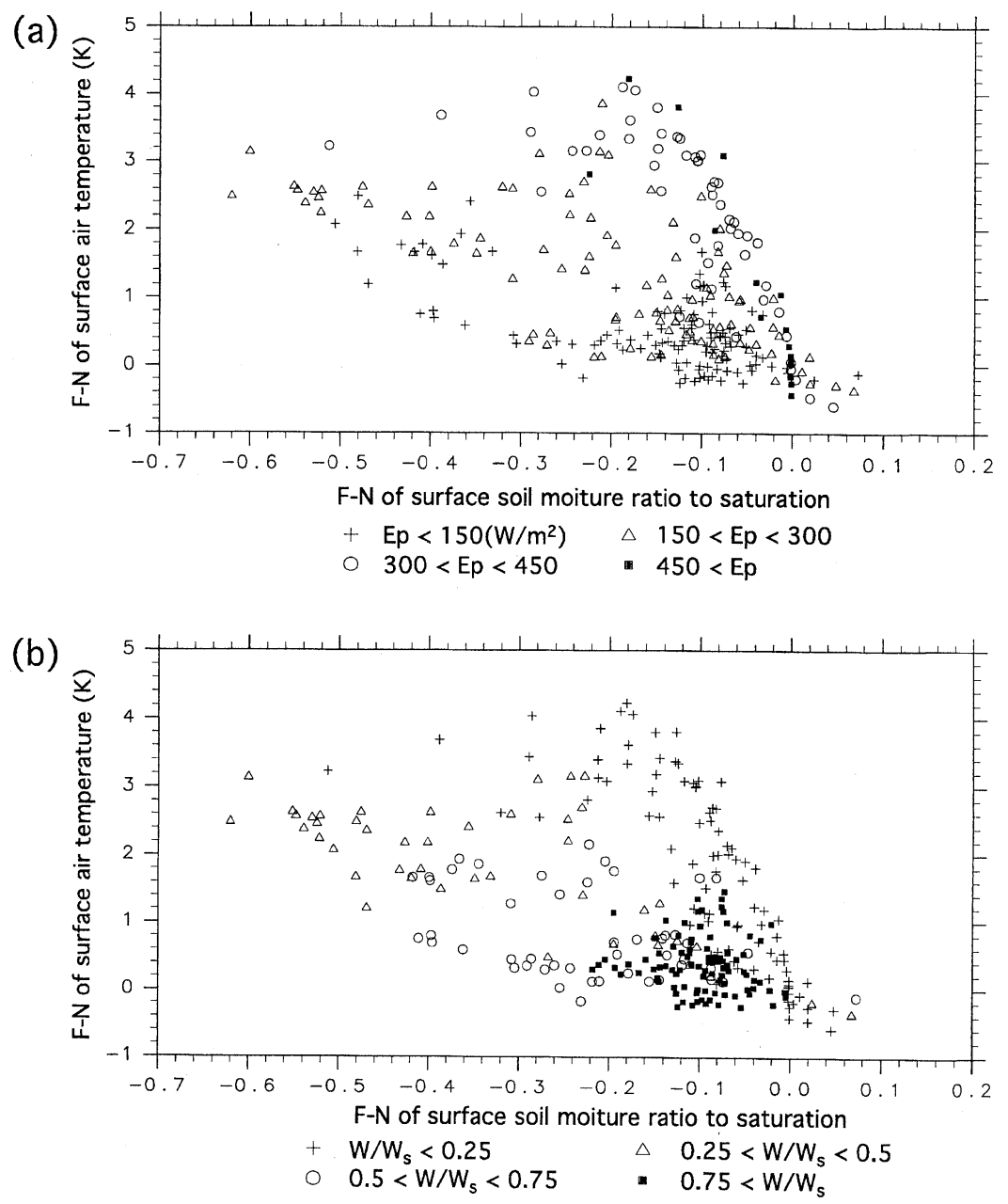

Fig. 9. (a) Difference $(\mathrm{F}-\mathrm{N})$ in surface soil moisture ratio to the saturation vs. surface air temperature. Plots are for points where the surface soil moisture difference is statistically significant at the $95 \%$ confidence level. Symbol types denote potential evaporation, $E_{p}$, in F run (see legends for categories). (b) As in (a) but symbol types denote surface soil moisture ratio to saturation, $W_{g} / W_{s}$, in $\mathrm{F}$ run (see legends for categories).

flux scheme are used: diffusion of volumetric water content, diffusion and gravity flux, and hydraulic potential gradient. The frozen soil permeability is included and excluded for two of them; diffusivity is 0.01 of that for unfrozen soil, or it is exponentially reduced with ice content. Sensitivity to snow infiltration and depression storage are also examined. The critical snow mass for snow infiltration in Table 1 is the minimum required to cause all rainfall and snowmelt to run off-part of them infiltrates into ground when snow is less than this. The depression storage parameter is an index for the capacity to hold excess water over saturation at the surface - the capacity is $2.5 \mathrm{~cm}$ depth of water when it equals 2 , and no capacity when 1 . Depression storage corresponds to water sustained at the surface of a subgrid-scale depressed topography. Evaporation and runoff are treated the same as saturated when an excess of water over saturation occurs.

The atmospheric condition is prescribed by the observations at Ogurtsovo $\left(54.9^{\circ} \mathrm{N}, 82.9^{\circ} \mathrm{E}\right)$, the former Soviet Union (Robock et al. 1995), in a region where high impact occurs in AGCM experiments. Data from January 1 to December 31, 1982, is used in this study, repeatedly given to the model to obtain an equilibrated seasonal cycle. Experiments with and without soil freezing ( $\mathrm{F}$ and $\mathrm{N}$ runs) are made, as in the AGCM experiment (Section 3), for each version of the model, detailed in Takata (1998). The calculated soil temperature, soil moisture, and snow cover agree reasonably well with observations (Takata 1998).

Table 2 shows the $\mathrm{F}-\mathrm{N}$ of surface soil moisture, evaporation, and surface temperature in JJA in each experiment. Those at the grid nearest to Ogurtsovo and the average in central Siberia in the GCM experiment are also listed. Surface soil moisture is lower in the $\mathrm{F}$ run than in the $\mathrm{N}$ run for all experiments, thereby leading to lower evaporation and higher surface temperature. Signs of differences in JJA are the 
(a)



contour interval $=1 \mathrm{~K}$

(b)

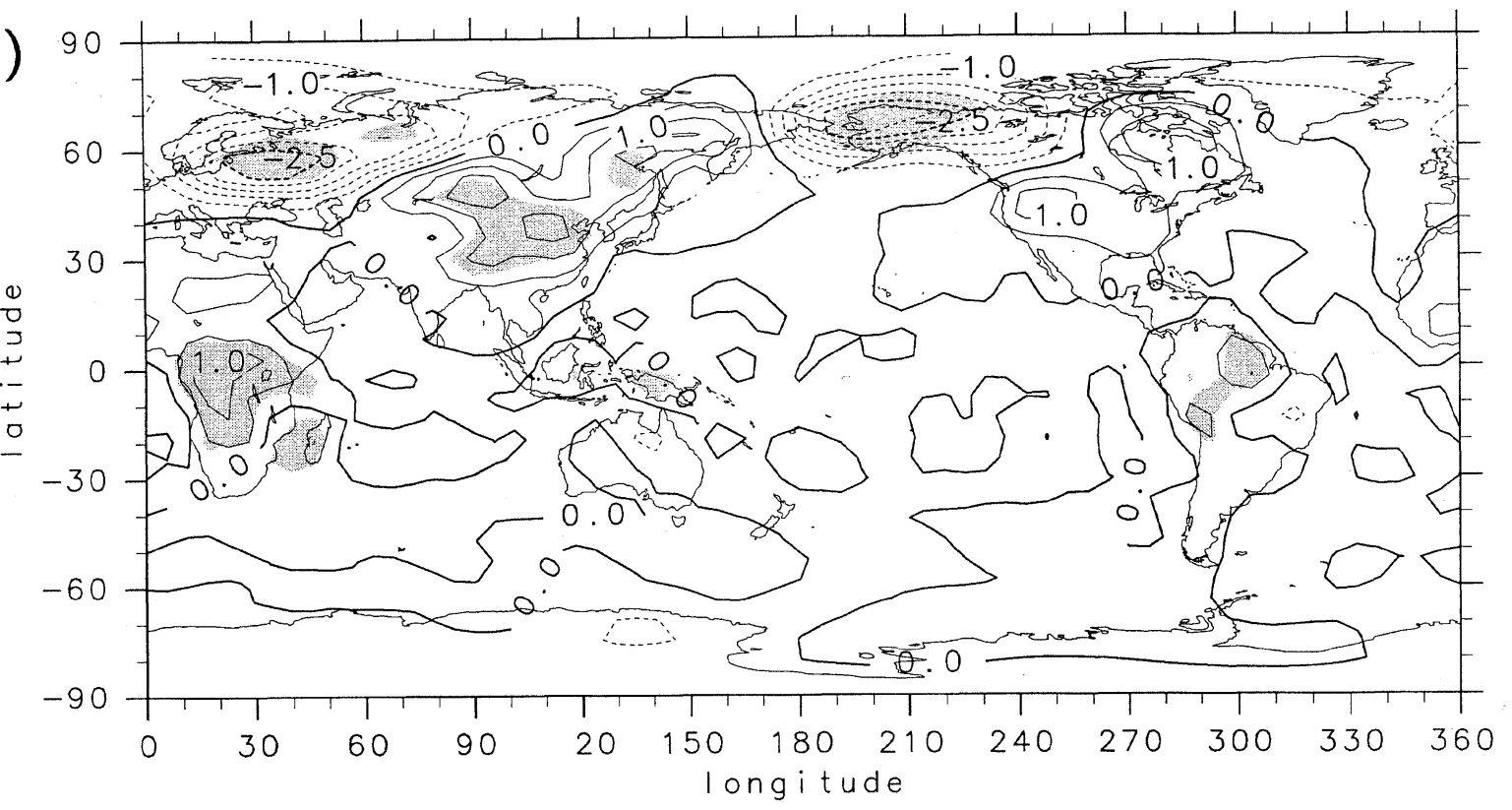

contour interval $=0.5 \mathrm{~K}$

Fig. 10. (a) Difference $(\mathrm{F}-\mathrm{N})$ in soil temperature in the bottom layer in winter (December-February) (contour interval: $1 \mathrm{~K}$ ). Dashed contours denote negative values. Shadings denote statistically significant regions at the $95 \%$ confidence level. (b) As in (a) but for surface air temperature (contour interval: $0.5 \mathrm{~K}$ ).

same for every experiment as in the AGCM, and do not depend on schemes or parameters. The magnitude of evaporation and temperature differences is, however, smaller in all one-dimensional experiments than that of the AGCM experiment, even in $\mathrm{D}(3)$, where schemes and parameters are the same as in the AGCM experiment, presumably because atmospheric conditions are prescribed at the same values in both $\mathrm{F}$ and $\mathrm{N}$ runs in the one-dimensional experi- ments. Evaporation and surface temperature differences could be amplified in AGCM experiments with land-atmosphere interaction such as evaporationprecipitation feedback.

In DJF, soil temperatures at a certain depth are appreciably higher by a few degrees, in the $\mathrm{F}$ run than in the $\mathrm{N}$ run (Table 3) due to latent heat of freezing, similar to the AGCM study. The $\mathrm{F}-\mathrm{N}$ of soil temperature is high when soil moisture content 
(c)
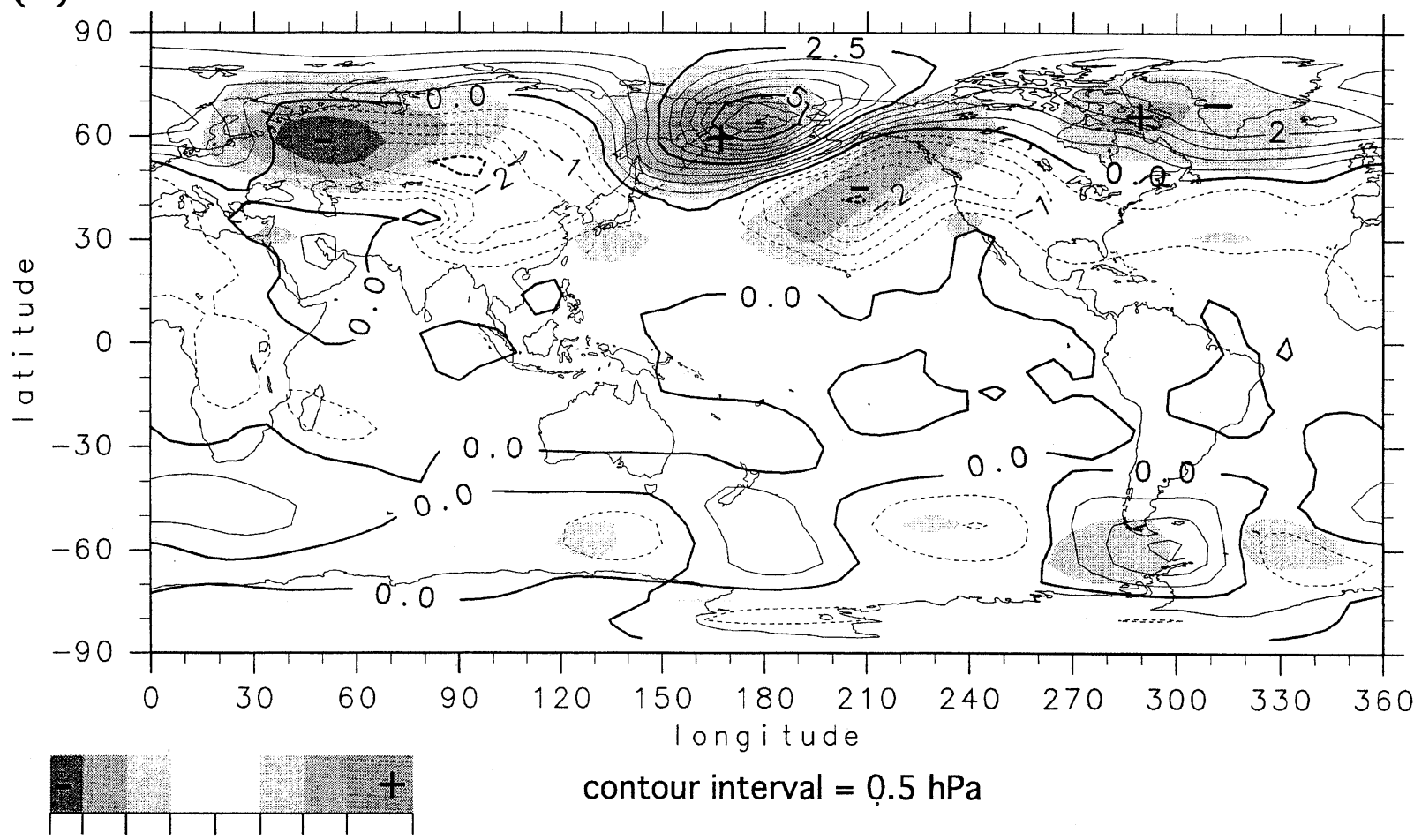

contour interval $=0.5 \mathrm{hPa}$

$-38-30-20-10 \quad 0 \quad 1020 \quad 30 \quad 45 \quad \mathrm{gpm}$

Fig. 10. (c) As in (a) but for sea level pressure (contour interval: $0.5 \mathrm{hPa}$ ) and $500 \mathrm{hPa}$ geopotential height (hatches; see legends for categories).
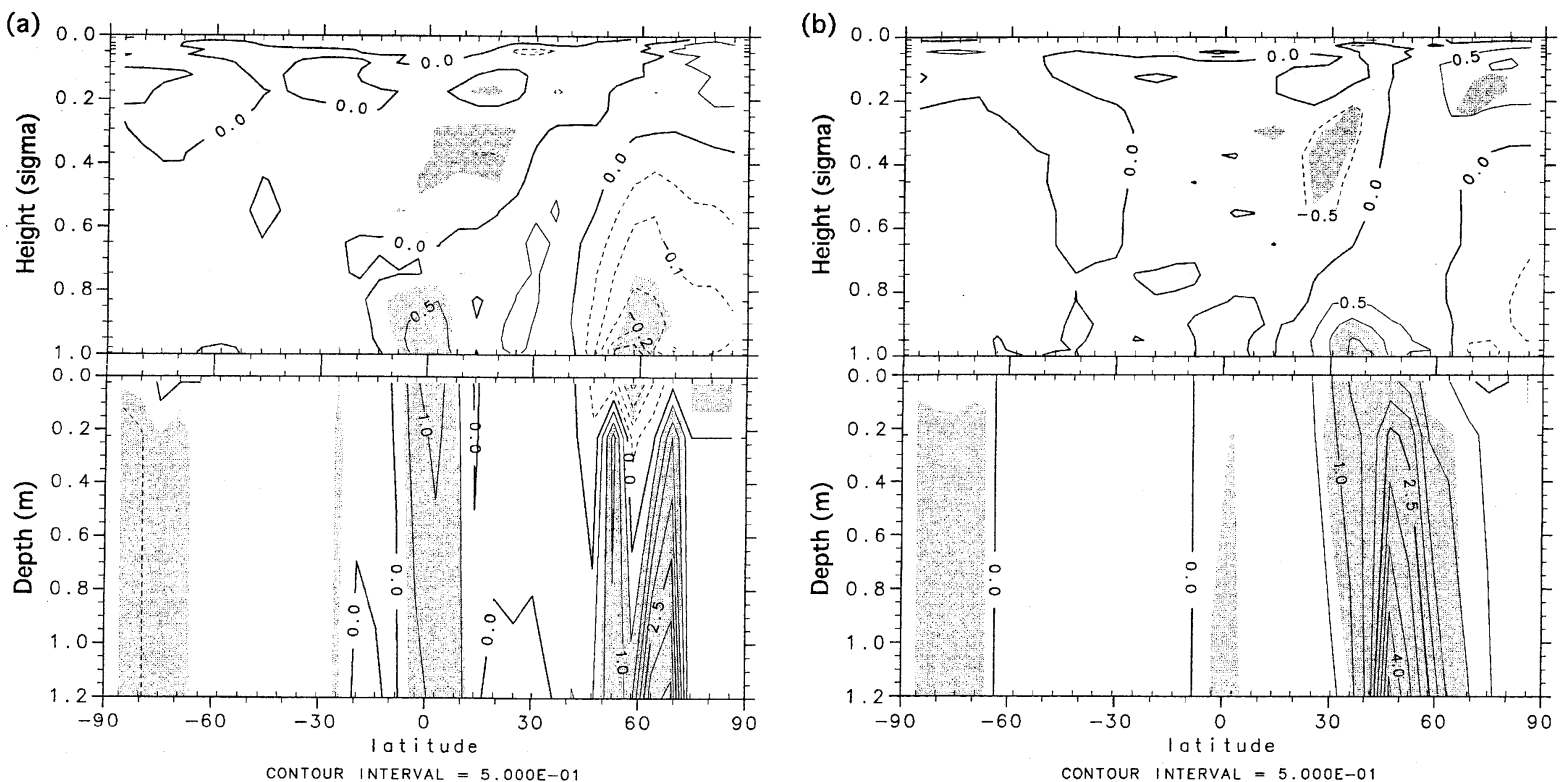

Fig. 11. Latitude-height section of differences $(\mathrm{F}-\mathrm{N})$ in winter (December-February) for atmospheric and soil temperatures at (a) $34^{\circ} \mathrm{E}$ and (b) $112^{\circ} \mathrm{E}$ (contour interval: $0.5 \mathrm{~K}$ ). Dashed contours denote negative values. Hatches denote statistically significant portions at the $95 \%$ confidence level. 
Table 1. List of one-dimensional experiments.

\begin{tabular}{lcccccccc}
\hline Exp. & $\begin{array}{c}\text { Total } \\
\text { depth } \\
(\mathrm{m})\end{array}$ & $\begin{array}{c}\text { No. of } \\
\text { layers }\end{array}$ & $\begin{array}{c}\text { Soil moisture } \\
\text { scheme }\end{array}$ & $\begin{array}{c}\text { Permeability } \\
\text { of frozen soil }\end{array}$ & $\begin{array}{c}\text { Porosity } \\
\text { snow mass } \\
\left(\mathrm{kgm}^{-2}\right)\end{array}$ & $\begin{array}{c}\text { Depression } \\
\text { storage } \\
\text { factor** }\end{array}$ & $\begin{array}{c}\text { Hydraulic } \\
\text { coefficients }\end{array}$ \\
\hline $\mathrm{D}(3)$ & 2 & 3 & Diffusion & No flux & 0.2 & 100 & 1 & $\mathrm{D}=1 \mathrm{E}-5$ \\
$\mathrm{D}(12)$ & 2 & 11 & Diffusion & No flux & 0.4 & 100 & 1 & $\mathrm{D}=1 \mathrm{E}-5$ \\
$\mathrm{D}$ & 4 & 22 & Diffusion & No flux & 0.4 & 100 & 1 & $\mathrm{D}=1 \mathrm{E}-5$ \\
$\mathrm{G}$ & $4^{*}$ & $22^{*}$ & Diffus. + grav. & No flux & 0.4 & 100 & 1 & $\mathrm{D}=1 \mathrm{E}-5$ \\
$\mathrm{GI}$ & $4^{*}$ & $22^{*}$ & Diffus. + grav. & Constant rate & 0.4 & 100 & 1 & $\mathrm{D}=1 \mathrm{E}-5 \mathrm{a}=0.01$ \\
$\mathrm{GID}$ & $4^{*}$ & $22^{*}$ & Diffus. + grav. & Constant rate & 0.4 & 100 & 2 & $\mathrm{D}=1 \mathrm{E}-5 \mathrm{a}=0.01$ \\
$\mathrm{GIR}$ & $4^{*}$ & $22^{*}$ & Diffus. + grav. & Constant rate & 0.4 & $1 . \mathrm{E}+10$ & 1 & $\mathrm{D}=1 \mathrm{E}-5 \mathrm{a}=0.01$ \\
$\mathrm{GIDR}$ & $4^{*}$ & $22^{*}$ & Diffus. + grav. Constant rate & 0.4 & $1 . \mathrm{E}+10$ & 2 & $\mathrm{D}=1 \mathrm{E}-5 \mathrm{a}=0.01$ \\
$\mathrm{P}$ & $4^{*}$ & $22^{*}$ & Potential & No flux & 0.4 & 100 & 2 & $\psi_{s}=-0.5 \mathrm{~B}=5$ \\
$\mathrm{PID}$ & $4^{*}$ & $22^{*}$ & Potential & Ice-dependent & 0.4 & 100 & 2 & $\psi_{s}=-0.5 \mathrm{~B}=5$ \\
\hline
\end{tabular}

* One layer of $1 \mathrm{~m}$ thick is added for soil temperature. Thus the total depth is $5 \mathrm{~m}$, and the number of layers is 23 for soil temperature but results are similar and referred to without discrimination.

** No depession storage is allowed when the factor is unity. The capacity of depession storage is $2.5 \mathrm{~cm}$ depth of water when the factor is two.

Table 2. Differences in summer (June-August) between experiments with and without soil freezing at Ogurtsovo. Those for averages in central Siberia and the grid-point nearest to Ogurtsovo in the AGCM are listed for comparison.

\begin{tabular}{lccc}
\hline Experiment & $\begin{array}{c}\text { Surface soil } \\
\text { moisture ratio to } \\
\text { saturation }\end{array}$ & $\begin{array}{c}\text { Evaporation } \\
\left(\mathrm{W} / \mathrm{m}^{2}\right)\end{array}$ & $\begin{array}{c}\text { Surface } \\
\text { temperature } \\
(\mathrm{K})\end{array}$ \\
\hline $\mathrm{D}(3)$ & -0.040 & -3.7 & 0.31 \\
$\mathrm{D}(12)$ & -0.078 & -15.6 & 0.52 \\
$\mathrm{D}$ & -0.080 & -16.4 & 0.54 \\
$\mathrm{G}$ & -0.019 & -4.0 & 0.12 \\
GI & -0.017 & -3.5 & 0.11 \\
GID & -0.010 & -2.0 & 0.05 \\
GIR & -0.108 & -21.6 & 0.72 \\
GIDR & -0.113 & -22.7 & 0.75 \\
P & -0.075 & -13.4 & 0.49 \\
PID & -0.073 & -13.3 & 0.48 \\
\hline GCM* (1 grid) & -0.038 & -34.2 & 3.25 \\
(central Siberia) & -0.103 & -14.7 & 2.60 \\
\hline
\end{tabular}

* GCM results are shown for comparison. '1 grid' denotes the value at the nearest grid to Ogurtsovo, and 'central Siberia' denotes the regional mean over $90^{\circ}-120^{\circ} \mathrm{E}, 40^{\circ}-65^{\circ} \mathrm{N}$.

is high, as mentioned at the beginning of this section. Surface temperature differences are small, but their signs are all positive due to large positive soil temperature differences attenuated by the thermal insulation of snow cover. It follows that the surface temperature can be higher in winter with soil freezing because of latent heat release, but its magnitude may not be so high - a few tenths of a degree - and easily canceled out by negative atmospheric changes caused by dynamical processes which are usually large in high latitudes.

The signs of soil freezing impact are also validated at Valdai $\left(58.0^{\circ} \mathrm{N}, 33.2^{\circ} \mathrm{E}\right)$, Russia, where the forcing data are available for 18 years. The same sensitivity experiments are conducted, and the signs of soil freezing impact are found to be the same as those at Ogurtsovo both in JJA and DJF. It is thus comfirmed further that the soil freezing impact shown in the AGCM experiments do not depend on soil moisture schemes or parameters. The results of Valdai experiments are saved for brevity, but a comparison with the observation will be mentioned in Section 7.

Note, in Table 2, that the F-N in JJA is considerably lower for G, GI, and GID runs than GIR and GIDR runs, associated with differences in snow infiltration parameters between the two groups; rainfall and snowmelt $P_{l}+M$ during the snow-cover season partly infiltrate and partly run off in G, GI, and GID, while $P_{l}+M$ totally infiltrates into GIR and GIDR. The different response to switching soil freezing on and off is explained by the difference in runoff 
Table 3. As in Table 2 but for averages in winter (December-February).

\begin{tabular}{|c|c|c|c|c|c|}
\hline \multirow[t]{2}{*}{ Exp. } & \multirow{2}{*}{$\begin{array}{c}\text { Surface } \\
\text { temperature } \\
(\mathrm{K})\end{array}$} & \multirow{2}{*}{$\begin{array}{c}\text { Uppermost soil } \\
\text { temperature } \\
(\mathrm{K})\end{array}$} & \multicolumn{2}{|c|}{$\begin{array}{l}\text { Max. soil temperature } \\
\text { change }\end{array}$} & \multirow{2}{*}{$\begin{array}{l}\text { Soil moisture } \\
\text { content in } \\
0-1 \mathrm{~m} \text { in F run } \\
(\mathrm{mm})\end{array}$} \\
\hline & & & $\begin{array}{l}\text { Temp. change } \\
(\mathrm{K})\end{array}$ & $\begin{array}{l}\text { Depth } \\
\text { (m) }\end{array}$ & \\
\hline $\mathrm{D}(3)$ & 0.037 & 0.16 & 0.70 & 1.2 & 69.136 \\
\hline $\mathrm{D}(12)$ & 0.18 & 0.93 & 2.22 & 0.7 & 130.47 \\
\hline $\mathrm{D}$ & 0.26 & 0.95 & 2.24 & 0.7 & 116.76 \\
\hline G & 0.090 & 0.19 & 0.43 & 0.7 & 34.114 \\
\hline GI & 0.15 & 0.42 & 1.17 & 0.5 & 69.931 \\
\hline GID & 0.24 & 0.85 & 1.96 & 0.32 & 106.69 \\
\hline GIR & 0.17 & 0.51 & 1.38 & 0.5 & 71.53 \\
\hline GIDR & 0.24 & 0.86 & 2.00 & 0.5 & 102.14 \\
\hline $\mathrm{P}$ & 0.36 & 1.39 & 3.15 & 0.5 & 187.21 \\
\hline PID & 0.47 & 1.87 & 3.94 & 0.32 & 228.86 \\
\hline GCM $^{*}$ (1 grid) & 1.35 & 1.22 & 1.50 & 1.2 & 22.885 \\
\hline (central Siberia) & 0.94 & 1.39 & 2.91 & 1.2 & 109.29 \\
\hline
\end{tabular}

* GCM results are shown for comparison. ' 1 grid' denotes the value at the nearest grid to Ogurtsovo, and 'central Siberia' denotes the regional mean over $90^{\circ}-120^{\circ} \mathrm{E}, 40^{\circ}-65^{\circ} \mathrm{N}$.

$$
\begin{gathered}
\text { partial } \\
\text { snow infiltration } \\
(G, G, G D)
\end{gathered}
$$

wit h

soil freezing

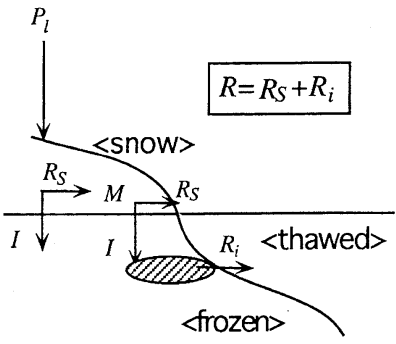

without soil freezing

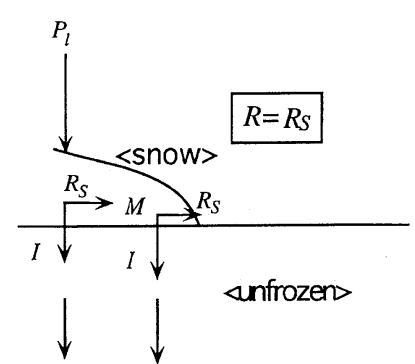

total

snow infiltration (GIR,GIDR)


Fig. 12. A schematic diagram of water fluxes related to runoff and snow for partial and total snow infiltration with and without soil freezing. The abscissa denotes time proceeding from left to right. $P_{l}$ is rainfall, $R_{s}$ runoff on snow, $I$ infiltration, $M$ snowmelt, $R_{i}$ runoff due to soil saturation, and $R$ total runoff. Hatches denote soil saturation.

as follows:

Water fluxes related to snow infiltration and runoff are schematically shown in Fig. 12. Abscissa denotes time proceeding from left to right. Experiments are classified into four categories: partial or total snow infiltration, and with or without soil freezing. Rather high rainfall $\left(P_{l}\right)$ occurs in the late snow-cover season at Ogurtsovo (Fig. 11b in Takata (1998)). $P_{l}$ partly infiltrates into soil $(I)$ and partly becomes runoff over snow $\left(R_{s}\right)$ for G, GI, and GID runs. $I$ is stored near the surface with soil freezing, and penetrates into deeper soil without freezing. For GIR and GIDR runs, all $P_{l}$ infiltrates into the soil, saturating the soil near the surface with soil freezing, while it penetrates into deeper soil in the absence of frozen soil. Then snowmelt $(M)$ begins. $M$ partly infiltrates $(I)$ and partly becomes runoff $\left(R_{s}\right)$ for G, GI, and GID runs. At this point, surface soil moisture is saturated with soil freezing, and a part of $I$ becomes runoff $\left(R_{i}\right)$, while all of $I$ infiltrates 
into deeper soil without soil freezing. For GIR and GIDR, all of $M$ infiltrates into soil. Soil near the surface has already been saturated with soil freezing, so the major part of $M$ becomes runoff $\left(R_{i}\right)$. In contrast, all of $M$ penetrates into deeper soil without soil freezing.

To summarize, total runoff is $R_{s}+R_{i}$ in G, GI, and GID runs with soil freezing; $R_{s}$ in G, GI, and GID without; $R_{i}$ in GIR and GIDR runs with freezing; and practically zero in GIR and GIDR without (note that $R_{s}$ and $R_{i}$ differ in each experiment). The difference $(\mathrm{F}-\mathrm{N})$ in runoff is $R_{i}$ for both partial and total snow infiltration. It is presumed from the saturated period that $R_{i}$ is higher in GIR and GIDR runs than in G, GI, and GID runs, because most of $M$ becomes $R_{i}$ in GIR and GIDR runs while part of $M$ becomes $R_{i}$ in G, GI, and GID runs. The larger $\mathrm{F}-\mathrm{N}$ of runoff in GIR and GIDR runs leads to lower surface soil moisture, thus causing a larger negative difference in evaporation and a larger positive difference in surface temperature in JJA. The impact of soil freezing therefore depends sensitively on runoff processes.

\section{Discussion}

GCM results (Section 5.2) show that soil freezing has continental-scale impacts; inclusion of soil freezing leads to the higher snowmelt runoff due to the impermeability of frozen soil, which causes the lower surface soil moisture in summer leading to marked local and remote impacts on the atmosphere. It is generally accepted that a frozen layer acts as an impermeable layer, so the ground water table remains near the surface and surface soil remains very wet; therefore a retreat of frozen soil leads to a deeper ground water table and a drier surface condition (Woo 1990). Our results appear to disagree with this observation, but it is a matter of a difference in viewpoints. The observational knowledge concerns the difference in summer surface conditions between warmer and colder climates, where soil is allowed to freeze and thaw under both climates. Our study focused on the impact of the freezing process itself, and the impact we discuss here is deduced from a comparison of climates with and without soil freezing. Soil freezing is restrained in the $\mathrm{N}$ run under a condition when soil freezing should occur. A comparison of such an imaginary condition ( $\mathrm{N}$ run) and a realistic condition ( $\mathrm{F}$ run) gives a picture of the role of soil freezing in forming the present mean climate rather than its variability. Note that a relationship similar to observation is indeed seen between surface soil moisture and the amount of frozen soil in interannual variations of the F run; i.e., frozen soil in summer decreases when and where surface temperature in summer is high, and surface soil moisture in summer decreases then and there, and vice versa.
Note also that including frozen soil permeability and ground depression storage reduces the impacts of soil freezing in JJA. Additional runoff in spring triggers soil freezing impacts in the subsequent season (Section 5.2), but adding these two processes increases soil moisture in spring by reducing runoff during snowmelt (Takata 1998). This reduction in impacts is also indicated in our onedimensional experiments (Table 2); the $\mathrm{F}-\mathrm{N}$ of soil moisture, evaporation, and surface temperature slightly lower in runs that consider frozen soil permeability and depression storage (compare G, GI and GID). Although differences are not large, they may become significant when land-atmosphere interaction is taken into account. The interactive impact of frozen soil permeability and depression storage should thus be examined carefully in future work.

In Section 4, it cannot be judged which run of the $\mathrm{F}$ and $\mathrm{N}$ runs is closer to observation in the AGCM experiment. We compared the results of the one-dimentional experiment at Valdai with the observation, since validation data such as runoff and evaporation are available there. Although the full study of model validation at Valdai is beyond the scope of this paper, it should be noted that the results in the F run is closer to the observation than in the $\mathrm{N}$ run. Runoff and evaporation agree well with the observation in the $\mathrm{F}$ run, while runoff is underestimated and evaporation is overestimated in the $\mathrm{N}$ run. The partitioning between runoff and evaporation is thus reproduced better in the $F$ run. The seasonal amplitude and interannual variation of surface soil moisture agree with the observation in the F run, while they are much smaller than the observation in the $\mathrm{N}$ run. The performance of the present AGCM is not remarkably improved by incorporating soil freezing because the overall performance of an AGCM depends on complex interplay among many processes. The one-dimensional experiments at Valdai however imply that incorporation of soil freezing should improve the land surface hydrological condition, and thus contribute to better reproducibility of the climate system.

\section{Concluding remarks}

The thermal and hydrological impacts of soil freezing, i.e., effects of latent heat of fusion and impermeability of frozen soil were studied, considering the interaction between the atmosphere and land surface. The CCSR/NIES AGCM with a multilayer soil model was used with seasonally varying climatological sea surface temperature. Although the soil model used in the AGCM is relatively simple, calculated global distributions of frozen soil agree well with observations and the annual cycle of soil moisture is validated favorably at several observational sites in frozen ground regions of Russia.

The impact of soil freezing found in this study 


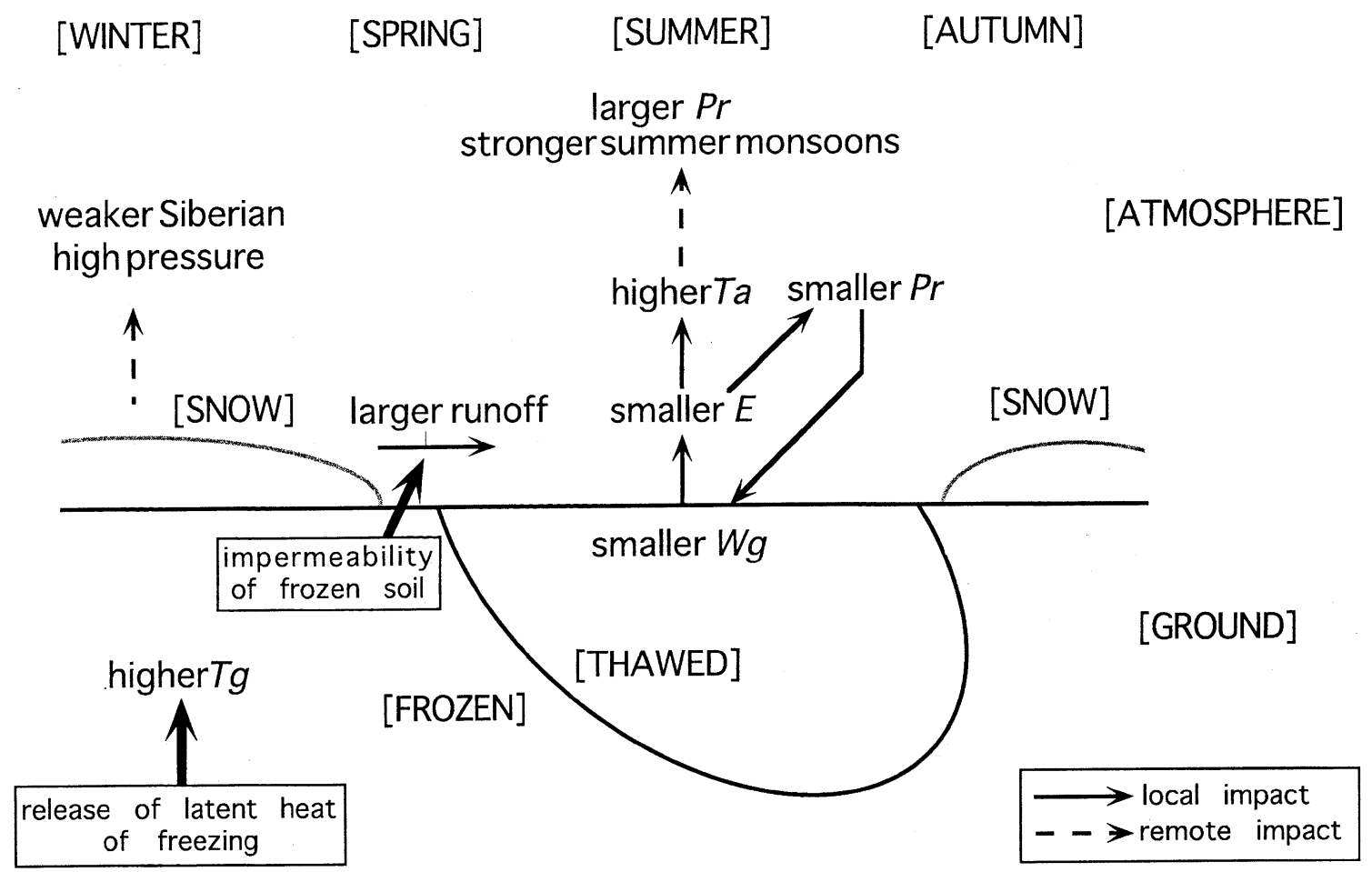

Fig. 13. A schematic diagram summarizing soil freezing impacts. The abscissa denotes time proceeding from left to right.

is summarized in Fig. 13. Abscissa denotes time proceeding from left to right. The inclusion of soil freezing leads to larger runoff of snowmelt in spring in frozen ground regions due to impermeability of frozen soil, leading to lower surface soil moisture, lower evaporation, and higher surface air temperature in summer in middle and high latitudes over land. This induces higher eastward water vapor flux and precipitation from Southeast Asia to the western subtropical Pacific. Precipitation is lower on middle Eurasian and North American Continents in mid-latitudes, which results from smaller evaporation there. In addition, it is found that the negative surface soil moisture difference is larger in high latitudes because of less available soil liquid water due to underlying frozen ground, and that the sensitivity of temperature change to soil moisture change is high in regions where potential evaporation is high.

In winter, the inclusion of soil freezing leads to higher deep soil temperatures in frozen ground regions due to latent heat release by freezing. The surface air temperature is higher in eastern Asia and lower in Europe due to changes in wind field induced by a weakened Siberian high.

Additional experiments using a one-dimensional landsurface model were conducted to examine whether the impacts of soil freezing were affected by hydrological schemes and parameters. The onedimensional model was modified from the landsurface scheme in the AGCM, and the atmospheric con- dition was specified at observed values at Ogurtsovo $\left(54.9^{\circ} \mathrm{N}, 82.9^{\circ} \mathrm{E}\right)$, where large impacts were found in the AGCM experiments. The signs of differences in summer are the same as in the AGCM study, regardless of hydrological schemes and parameters. It is also shown that soil freezing impacts were related to the runoff process in a complicated way, and that the inclusion of frozen soil permeability and depression storage may reduce the impacts of soil freezing in summer because they reduce spring runoff. Both soil and surface temperatures are positive in winter impact, but surface temperature inpact is so small that atmospheric processes may mask it.

It is shown in this study that the impacts of soil freezing on the climate system are closely related to snow processes and are explained by the difference in snowmelt runoff. It is thus important to clarify the role of frozen ground in relation to snow processes in future studies. The effects of frozen soil permeability and depression storage should also be studied focusing on the relationship between soil freezing and runoff. The effect of canopy, such as shading solar incidence, precipitation interception, and a sophisticated treatment of stomatal resistance, including water uptake from the root zone, should also be considered.

\section{Acknowledgments}

We thank Profs. A. Robock and K. Vinnikov for providing data on Russian stations. We also thank 
two anonymous reviewers for their valuable comments. This study was supported in part by Domestic Research Fellowship of Japan Science and Technology Corporation, and by a Grant-in-Aid for Scientific Research from the Ministry of Education, Science, and Culture of Japan.

\section{References}

Anisimov, O.A. and F.E. Nelson, 1997: Permafrost zonation and climate change in the Northern Hemisphere: results from transient general circulation models. Clim. Change, 35, 241-258.

Arakawa, A. and W.H. Schubert, 1974: Interaction of a cumulus cloud ensemble with the large-scale environment. Part I. J. Atmos. Sci., 31, 674-701.

Baker, J.M. and E.J.A. Spaans, 1997: Mechanics of meltwater movement above and within frozen soil. CRELL Special Report, 97-10, Proc. Int. Symp. on Physics, Chemistry and Ecology of Seasonally Frozen Soils, Fairbanks, Alaska, 1997, 31-36.

Bonan, G.B., 1991: A biophysical surface energy budget analysis of soil temperature in the boreal forests of interior Alaska. Water Resour. Res., 27, 767-781.

, D. Pollard and S.L. Thompson, 1992: Effects of boreal forest vegetation on global climate. Nature, 359, 716-718.

Charney, J.G., W.J. Quirk, S.-H. Chow and J. Kornfield, 1977: A comparative study of the effects of albedo change on drought in semi-arid regions. J. Atmos. Sci., 34, 1366-1385.

Delworth, T. and S. Manabe, 1989: The influence of soil wetness on near-surface atmospheric variability. $J$. Climate, 2, 1447-1462.

Dickinson, R.E. and P. Kennedy, 1992: Impacts on regional climate of Amazon deforestation. Geopys. Res. Lett., 19, 1947-1950.

Dostovalov, B.N. and V.A. Kudryavtsev, 1967: General Theory of Frozen Ground, Moscow University Press (in Russia). Flerchinger, G.N. and K.E. Saxton 1989: Simultaneous heat and water model of a freezing snow-residue-soil system: I. Theory and development. Trans. ASAE, 32(2), 565-571.

Gavrilova, M.K., 1993: Climate and Permafrost. Permafrost and Periglacial Processes, 4, 99-111.

Grigorjan, S., E. Guseva and M. Krass, 1989: Some mathematical models for permafrost. GeoJournal, 18.4, 429-439.

Henderson-Sellers, A. and V. Gornitz, 1984: Possible climatic impacts of land cover transformations, with particular emphasis on tropical deforestation. Clim. Change, 6, 231-258.

Hinzman, L.D. and D.L. Kane, 1992: Potential response of an Arctic watershed during a period of global warming. it J. Geophys. Res, 97 (D3), 2811-2820.

IPCC, 1996a: Climate Change 1995, The Science of Climate Change. J.T. Houghton, L.G. Meira Filho, B.A. Callender, N. Harris, A. Kattenberg and K. Maskell (Eds.) Cambridge University Press, Cambridge, UK, pp. 572.

- $1996 \mathrm{~b}$ : Climate Change 1995, Impacts, Adaptations and Mitigation of Climate Change: ScientificTechnical Analysis. R.T. Watson, M.C. Zinyowera,
R.H. Moss and D.J. Dokken (Eds.) Cambridge University Press, Cambridge, UK, pp. 879.

Kane, D.L., L.D. Hinzman and J.P. Zarling, 1991: Thermal response of the active layer to climatic warming in a permafrost environment. Cold Reg. Sci. Technol., 19, 111-122.

Kinoshita, S. (Ed.), 1982: Physics of Frozen Soil, Morikita Pub. Co. Tokyo, Japan, pp. 227 (in Japanese).

Koster R.D. and M.J. Suarez, 1995: Relative contributions of land and ocean processes to precipitation variability. J. Geophys. Res., 100, 13775-13790.

Lafleur, P.M. and W.R. Rouse, 1995: Energy partitioning at treeline forest and tundra sites and its sensitivity to climate change. Atmospheric-Ocean, 33(1), 121-133.

Le Treut, H. and Z.-X. Li., 1991: Sensitivity of an atmospheric general circulation model to prescribed SST changes: feedback effects associated with the simulation of cloud optical properties. Clim. Dyn., $\mathbf{5}$, $175-187$.

Li, C. and M. Yanai, 1996: The onset and interannual variability of the Asian summer monsoon in relation to land-sea thermal contrast. J. Climate, 9, 358-375.

Louis, J., 1979: A parametric model of vertical eddy fluxes in the atmosphere. Bound. Layer Meteor., 17, 187-202.

Mao, J. and A. Robock, 1998: Aurface air temperature simulations by AMIP General Circulation Models: Volcanic and ENSO Signals and Systematic Errors. J. Climate, 11, 1538-1552.

McFarlane, N.A., 1987: The effect of orographically excited wave drag on the general circulation of the lower stratosphere and troposphere. J. Atmos. Sci., 44, 1775-1800.

Mellor, G.L. and T. Yamada, 1982: Development of a turbulence closure model for geophysical fluid problems. Rev. Geophys. Space Phys., 20, 851-875.

Mitchell, J.F.B. and D.A. Warrilow, 1987: Summer dryness in northern mid-latitudes due to increased $\mathrm{CO}_{2}$. Nature, 330, 238-240.

Nakajima, T., M. Tsukamoto, Y. Tsushima and A. Numaguti, 1995: Modeling of the radiative process in a AGCM. Climate System Dynamics and Modelling, Climate System Dynamics and Modeling, I3, Center for Climate System Research, University of Tokyo, Tokyo, 104-123.

Nakano, Y. and J. Brown, 1972: Mathematical modeling and validation of the thermal regimes in tundra soils, Barrow, Alaska. Arct. Alp. Res., 4, 19-38.

Nitta, T., 1987: Convective activities in the tropical western Pacific and their impact on the Northern Hemisphere summer circulation. J. Meteor. Soc. Japan, 65, 373-90.

Numaguti, A., 1999: Origin and recycling processes of precipitating water over the Eurasian continent: experiments using an atmospheric general circulation model. J. Geophys. Res., 104, 1957-1972.

-, M. Takahashi, T. Nakajima and A. Sumi, 1995: Development of an atmospheric general circulation model. Climate System Dynamics and Modelling, Reports of A New Program for Creative Basic Re- 
search Studies, I-3, Center for Climate System Research, Univ. Tokyo, 1-27.

Osterkamp, T.E. and A.H. Lachenbruch, 1990: Thermal regime of permafrost in Alaska and predicted global warming. J. Cold Regions Engrg., ASCE, 4(1), 3842.

Phillips, T.J., 1995: Documentation of the AMIP models on the World Wide Web. Bull. Amer. Meteor. Soc., 77, 1191-1196. (http://wwwpcmdi.llnl.gov/amip/AMIP1/amip1.html)

Robock, A., K.Ya. Vinnikov, C.A. Schlosser, N.A. Speranskaya and Y. Xue, 1995: Use of midlatitude soil moisture and meteorological observations to validate soil moisture simulations with biosphere and bucket models. J. Climate, 8, 15-35.

Rouse, W.R., D.W. Carlson and E.J. Weick, 1992: Impacts of summer warming on the energy and water balance of wetland tundra. Clim. Change, 22, 305326.

Rowell, D.P. and C. Blondin, 1990: The influence of soil wetness distribution on short range rainfall forecasting in the western African Sahel. Quart. J. Roy. Meteor. Soc., 116, 1471-1485.

Shen, X., M. Kimoto and A. Sumi, 1998: Role of land surface processes associated with interannual variability of broad-scale Asian summer monsoon as simulated by the CCSR/NIES AGCM. J. Meteor. Soc. Japan, 79, 217-236.

Shoop, S.A. and S.R. Bigl, 1997: Moisture migration during freeze and thaw of unsaturated soils: modeling and large scale experiments. Cold Reg. Sci. Technol., 25, 33-45.

Shukla, J. and Y. Mintz, 1982: Influence of land-surface evapotranspiration on the Earth's climate. Science, 215, 1498-1501.

Takata, K., 1998: Modeling the Thermal and Hydrologica Impacts of Frozen Ground on the Climate System. Doctoral Dissertation in Geoscience, the University of Tsukuba. and M. Kimoto, 1998: Impact of soil freezing on the continental-scale seasonal cycle simulated by a general circulation model. Proc. 7th Internat. Conf. on Permafrost, 1998, Yellowknife, N.W.T., Canada, 1035-1042.

Taylor, G.S. and J.N. Luthin, 1978: A model for coupled heat and moisture transfer during soil freezing. Can. Geotech. J., 15, 548-555.

Viterbo, P., A.C.M. Beljaars, J.-F. Mahfouf and J. Teixiera, 1999: The representation of soil moisture freezing and its impact on the stable boundary layer. Quart. J. Roy. Meteor. Soc., conditionally accepted.

Waelbroeck, C., 1993: Climate-soil processes in the presence of permafrost: a systems modelling approach. Ecol. Modelling, 69, 185-225.

Walker, J. and P.R. Rowntree, 1977: The effect of soil moisture on circulation and rainfall in tropical model. Quart. J. Roy. Meteor. Soc., 103, 29-46.

Wilson, M.F., A. Henderson-Sellers, R.E. Dickinson and P.J. Kennedy, 1987: Investigation of the sensitivity of the land-surface parameterization of the NCAR community climate model in regions of tundra vegetation. J. Climatol., 7, 319-343.

Webster, P.J. and S. Yang, 1992: Monsoon and ENSO: Selectively interactive systems. Quart. J. Roy. Meteor. Soc., 118, 877-926.

Woo, M.-K., 1990: Consequences of climatic change for hydrology in permafrost zones. J. Cold Regions Engrg., ASCE, 4(1), 15-20.

Yang, Z.L., R.E. Dickinson, A. Robock and K.Ya. Vinnikov, 1997: Validation of the BiosphereAtmosphere Transfer Scheme with Russian snow cover and meteorological observational data. J. Climate, 10, 353-373.

Yasunari, T., A. Kitoh and T. Tokioka, 1991: Local and remote responses to excessive snow mass over Eurasia appearing in the northern spring and summer climate -a study with the MRI-GCM-. J. Meteor. Soc. Japan, 69, 473-487. 


\section{大陸スケールの季節変化に対する凍土のインパクトに関する数值的研究}

\section{高田久美子}

(科学技術振興事業団・国立環境研究所)

\section{木本昌秀}

（東京大学気候システム研究センター）

凍土の気候システムに対する熱的・水文的インパクトについて大気大循環モデル (AGCM) を用いて調 べた。土壤凍結を入れた実験と入れない実験、即ち凍結融解の潜熱と凍結時の不透水性を入れた実験と入 れない実験の差から、土㙵凍結を考慮することによって夏季に中高緯度陸上の地表気温が高くなることが 示された。これによって東南アジアで水蒸気フラックスと降水が強化する。夏季の陸上の高温は、表層の 土壤水分が少なくなって、蒸発が減少するためである。表層の土壤水分が少なくなるのは、春季に凍土の 不透水性によって融雪水の流出が増大寸るためと、土壇の深層が涷結していることによって蒸発しうる液 体の土壤水分が少ないためである。大陸の中央部では、蒸発量が小さくなることによって降水量が小さく なる。また、可能蒸発量が大きいところでは土壤水分の変化に対する気温変化の感度が大きいことが示さ れた。冬季には、凍土域の土壤深層の温度は凍結潜熱によって高くなるが、地表気温の変化は大気の力学 的な応答によってより強く支配されていると見られる。様々なスキームやパラメタを用いた 1 次元陸面過 程モデルでも AGCM 実験と同様なインパクトが得られた。 